\title{
Lithological indicators of discontinuities in mountain soils rich in calcium carbonate in the Polish Carpathians
}

\author{
Joanna Beata KOWALSKA* iD https://orcid.org/oooo-0002-4086-5696; e-mail: joanna.kowalska@urk.edu.pl \\ Bartłomiej KAJDAS² iD https://orcid.org/oooo-0002-1674-726X; e-mail: xszerlit@gmail.com

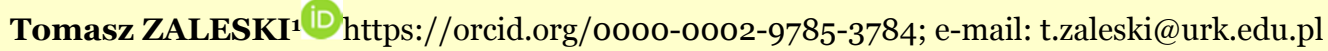 \\ ${ }^{*}$ Corresponding author \\ 1 Depatment of Soil Science and Agrophysics, University of Agriculture, Al. Mickiewicza 21, 31-12o Kraków, Poland \\ 2 Natural Science Education Centre, Jagiellonian University, Gronostajowa 5, 30-387 Kraków, Poland
}

Citation: Kowalska JB, Kajdas B, Zaleski T, et al. (2020) Lithological indicators of discontinuities in mountain soils rich in calcium carbonate in the Polish Carpathians. Journal of Mountain Science 17(5). https://doi.org/10.1007/s11629-019-5842-8

(C) The Author(s) 2020.

\begin{abstract}
Six soils located within the Polish Carpathians, developed on calcium carbonate-rich sedimentary parent materials and representing various reference groups, were investigated in order to detect the lithic discontinuity. We propose using a multidirectional approach to assess the lithic discontinuity in these soils, one that includes grain size distribution, geochemical composition, heavy mineral content and micromorphology, supported by a traditional soil survey. A further aim of this process was to identify the possible admixture of allochthonous material of aeolian origin. The studied soils presented lithic discontinuities mostly at the contact of underlying calcium carbonate-rich coarsegrained slope deposits with the overlaying colluvium layer having a lower content of rock fragments. The significant changes in grain size distribution, especially in the silt and sand content, as well as high Uniformity Values and partially, high Lithological Discontinuity Index values, confirmed the occurrence of a lithic discontinuity in all studied soils. High heterogeneity in the soil profiles was also confirmed by the distribution of the major oxides; however, their distribution did not clearly indicate the lithic discontinuity. The most visible distinctions were noted from $\mathrm{CaO}$ content, which resulted from the deposition of carbonate-free materials (aeolian silts)
\end{abstract}

Received: 09-Oct-2019

Revised: 06-Jan-2020

Accepted: 01-April-2020 and their mixing with the calcium carbonate-rich parent material. Furthermore, the analysis of heavy mineral content confirmed the allochthonous origin of the upper (and in some cases also the middle) parts of all profiles, which was manifested by the presence of highly weathering-resistant minerals such as zircon, epidote and various types of garnets. The micromorphological features of some of the studied soils showed distinctiveness within the soil profile, manifested by changes in b-fabric pattern, the occurrence and distribution of secondary carbonate and the coarse and fine coarse and fine ratio. Based on the high content of silt within the upper and middle parts of the soils, the content of $\mathrm{Hf}$ and $\mathrm{Zr}$, as well as the higher content of weathering-resistant minerals, admixture of aeolian silt could be considered in some of the studied soils, yet with weak character. However, the dominance of minerals typical for metamorphic and igneous rocks suggested that the supply of aeolian silt was associated with loess covers rather than local sedimentary material.

Keywords: Lithic discontinuities; Heavy minerals; Geochemistry; Slope processes; Micromorphology; Uniformity Values

\section{Notation:}

\begin{tabular}{|l|l|}
\hline Outcrop symbols & \\
\hline LDI1, LD2 & Lithological Discontinuity Index \\
\hline UV1, UV2 & Uniformity Values \\
\hline
\end{tabular}




\begin{tabular}{|l|l|}
\hline \multicolumn{2}{l}{ Mineral abbreviations } \\
\hline $\mathrm{Adr} / \mathrm{Grs}$ & Andradite/ Grossular \\
\hline $\mathrm{Alm}$ & Almandine \\
\hline $\mathrm{Alm} / \mathrm{Grs}$ & Almandine/ Grossular \\
\hline $\mathrm{Ca}-\mathrm{Am}$ & Ca-Amphibole \\
\hline $\mathrm{Ep}$ & Epidote \\
\hline $\mathrm{Ilm}$ & Ilmenite \\
\hline $\mathrm{Na}-\mathrm{Am}$ & Na-Amphibole \\
\hline Ortho-Am & Ortho-Amphibole \\
\hline Prp & Pyrope \\
\hline $\mathrm{Py}$ & Pyrite \\
\hline $\mathrm{TiO}$ & Titanium oxide \\
\hline $\mathrm{Zrn}$ & Zircon \\
\hline
\end{tabular}

\section{Introduction}

The origin and development of heterogeneous soils has been the subject of many studies (Ahr et al. 2012; Butler 1959; Kowalska et al. 2016; Lorz and Phillips 2006; Schaetzl 1998; Waroszewski et al. 2013, 2015). According to some authors, soil heterogeneity may be the result of geomorphological activities such as slope processes, surface erosion and deposition and admixture of allochthonous substrates (Waroszewski et al. 2018a, 2018b) The influence of such processes contributes to high heterogeneity in terms of parent material, grain size distribution and the mineralogical and geochemical properties that can be seen in these soils (Bockheim and Douglass 2006; Kacprzak and Derkowski 2007; Kowalska et al. 2017). Often, the heterogeneity within the soil profile may be distinguished as a lithological discontinuity, as seen in, e.g. Arnold (1968); Ligeza (2009); Lorz (2008); Lorz and Phillips (2006); Schaetzl (1998); Schaetzl and Anderson (2005); Waroszewski et al. (2015); Weindorf et al. (2015). In the applicable World Reference Base for Soil Resources (WRB) classification, the term 'lithological discontinuity' has been replaced by 'lithic discontinuity' and is defined as a clear or abrupt change of particle size distribution or mineralogical composition within the soil profile and may be an expression of differences in age or origin of soil parent material (IUSS Working Group WRB 2014).

Lithic discontinuities have been documented in different climate zones all over the world (e.g. Ahr et al. 2012; Kowalska et al. 2016; Ligeza 2009; Lorz and Phillips 2006; Schaetzl 1998; Waroszewski et al. 2015). Many different variations of Quaternary sediments have been recognized (Table 1). For instance, Ahr et al. (2012) described a lithologically and chronologically distinct stratigraphic unit, separated by a lithic discontinuity between sandy material weathered from sandstone bedrock and the underlying argillic horizon in a subtropical climate. In a like manner, lithic discontinuities have been seen at the junction of the eluvial (sandy loam, loam, or silt loam textural class) and illuvial horizons (clay, clay loam, or sandy clay loam textural class) in studies carried out by Bockheim (2016) in various soils of the United States.

Lorz and Philips (2006) documented a lithic discontinuity in Cambisols in Central Europe between the upper part of the soil profile, which was sandy loess, and a lower layer derived from weathered rhyolite. Also, Küfmann (2008) documented lithic discontinuities within Cambisols in the Northern Calcareous Alps and found a distinction between substantial aeolian addition (silt, fine sand, mica) and limestone subtypes with varying crack-fillings.

An abrupt texture change between the topsoil and subsoil indicating the presence of a lithic discontinuity was described by Musztyfaga and Kabała (2015) within the Albeluvisols of Lower Silesia of SW Poland, occurring at the contact of underlying loam and overlying sand. The soils investigated by Krasilnikov et al. (2005) showed a variety of evidence of discontinuities in soils, which had contrasting changes in colour (hue) and irregular rock fragment and sand content distribution. Furthermore, lithic discontinuities may be also formed in anthropogenic soils, where cultural layers overlay the natural horizon of soils; these were recognizable by the change of size and quantity of sand (Kowalska et al. 2016).

Some authors have described specific lithic discontinuities within mountainous areas, where the various autochthonous regoliths or mantle have been covered by aeolian loess. Waroszewski et al. (2015) described a lithic discontinuity within Podzols in the Stołowe Mts. of Poland, exhibited by a vertically differentiated sequence between a dense, skeletal and massive sandstone layer, comprising usually $\mathrm{Bs}$ and $\mathrm{BC}$ horizons, and the uppermost, relatively young layer, consisting of loose sandy material. Similarly, Martignier and Verrecchia (2013) noted discontinuities in the Swiss Jura Mts. among the Mesozoic limestone bedrocks and various superficial deposits such as 
Table 1 Soil properties used to lithic discontinuity detection given in the literature.

\begin{tabular}{|c|c|}
\hline Indicator & Author(s) \\
\hline Textural contrast & $\begin{array}{l}\text { Bockheim (2016); Bucci et al. (2016); Hall et al. (2005); Holliday et al. (2014); Ibrahim et al. } \\
\text { (2014); Jaworska et al. (2014); Kacprzak and Salamon (2013); Kowalska et al. (2016); } \\
\text { Kowalska et al. (2017); Ligęza 2009; Lorz (2008); Lorz et al. (2013); Musztyfaga and Kabała } \\
\text { (2015); Philips (2004, 2007); Pike et al. (2010); Sauer et al. (2015); Schaetzl (1998); Yang et } \\
\text { al. (2016), Waroszewski et al. (2013, 2015, 2016); Weindorf et al. (2015) }\end{array}$ \\
\hline Clay enrichment & $\begin{array}{l}\text { Bockheim and Hartemink (2013); Gunal and Ransom (2006); Martignier and Verrecchia } \\
\text { (2013) }\end{array}$ \\
\hline Loess accumulation & Bucci et al. (2016); Lorz et al. (2013); Martignier and Verrecchia (2013) \\
\hline Structure changes & Asikainen et al (2007); Ibrahim et al. (2014); Migoń and Kacprzak (2014) \\
\hline $\begin{array}{l}\text { Rock fragments } \\
\text { differentiation }\end{array}$ & Caspari et al. (2006); Costantini and Damiani (2004); Weindorf et al. (2015) \\
\hline Rock fragments shape & Kowalska et al. (2017); Krasilnikov et al. (2005); Priori and Costantini (2010) \\
\hline $\begin{array}{l}\text { Distinct stratigraphy } \\
\text { units }\end{array}$ & $\begin{array}{l}\text { Ahr et al. (2012); Asikainen et al (2007); Fernández-Lavado et al. (2007); Holliday et al. (2014); } \\
\text { Kacprzak and Salamon (2013); Krasilnikov et al. (2005); Lorz et al. (2013) }\end{array}$ \\
\hline $\begin{array}{l}\text { Content of coarse } \\
\text { fragments }\end{array}$ & $\begin{array}{l}\text { Fernández-Lavado et al. (2007); Holliday et al. (2014); Kowalska et al. (2017); Liebens } \\
\text { (1999)*; Migoń and Kacprzak (2014); Yang et al. (2016); Schaetzl (1998); Waroszewski et al. } \\
(2016)\end{array}$ \\
\hline Colour & Asikainen et al. (2007); Holliday et al. (2014) \\
\hline $\begin{array}{l}\text { Mineralogical } \\
\text { composition }\end{array}$ & $\begin{array}{l}\text { Ande and Senjobi (2010); Howard and Olszewska (2011); Jaworska et al. (2014); Kuzila } \\
(1995)^{*} \text {; Ligęza 2009; Weindorf et al. (2015) }\end{array}$ \\
\hline Heavy minerals & Chapman and Horn $(1968)^{*}$; Waroszewski et al. (2013) \\
\hline Clay minerals & Costantini and Damiani (2004); Krasilnikov et al. (2005) \\
\hline $\begin{array}{l}\text { Micromorphological } \\
\text { features }\end{array}$ & Federoff et al. (2010); Sauer et al. (2015) \\
\hline
\end{tabular}

moraines, cover-beds, loess deposits and cryoclasts. Kacprzak and Salamon (2013) documented a discontinuity between loess and flysch regolith as well as textural discontinuities between flyschderived slope materials and underlying weathered flysch in situ within Cambisols, Stagnosol and Albeluvisols in the Carpathian Foothills in Poland.

Tracking the occurrence and formation of lithic discontinuities can sometimes be problematic, especially in mountain environments, as they are characterized by a number of variable factors, such as reworking processes and admixture of foreign materials. Only a few studies have attempted in a more comprehensive way to identify and characterize soils with lithic discontinuities in mountainous areas (e.g. Birkeland et al. 2003, Waroszewski et al. 2018a, Waroszewski et al. 2020).

In the Polish Carpathians, where sedimentary rocks dominate, materials are constantly remodelled on the slopes, and the lithic discontinuities are not always easily recognizable. Furthermore, the scale of transformation of Carpathian soils has not been fully explained. Therefore, these deposits need to be characterized for their chemical, geochemical and mineralogical composition in the landscape, for their possible mixing on the slope and finally to identify possible lithic discontinuities in order to comprehensively understand soil genesis in temperate mountain zones (Schaetzl and Anderson 2005). We propose using a multidirectional approach toward assessment of the heterogeneity of the soil, including grain size distribution, coarse fragments, geochemical composition, analysis of heavy minerals and micromorphology and supported by a traditional soil survey, for identification of lithic discontinuities in calcium carbonate-rich soil in the Polish Carpathians (South Poland). A further aim is to identify the possible admixture of allochthonous material of aeolian origin.

\section{Study Area}

The Polish Carpathians occupy an area of $19,600 \mathrm{~km}^{2}$, mostly comprised of the Western Carpathian region, which covers an area of about $17,100 \mathrm{~km}^{2}$. The Western Carpathians are divided into the Outer Western Carpathians and Inner Western Carpathians (Warszyńska 1995). The Inner and Outer Carpathians differ from each other geologically. The Inner Carpathians are formed from a crystalline core with a Permian-Mesozoic sediment cover. Plutonic and metamorphic rocks 
dominate (e.g. granitoids and gneisses) (Oszczypko 1995). The Outer Carpathians are characterized by the occurrence of mutually shifting beds of sandstone, mudstone and claystone, termed as Carpathians flysch. Also, carbonate rocks such as limestone and marl as well as siliceous rocks are often found (Oszczypko 1995).
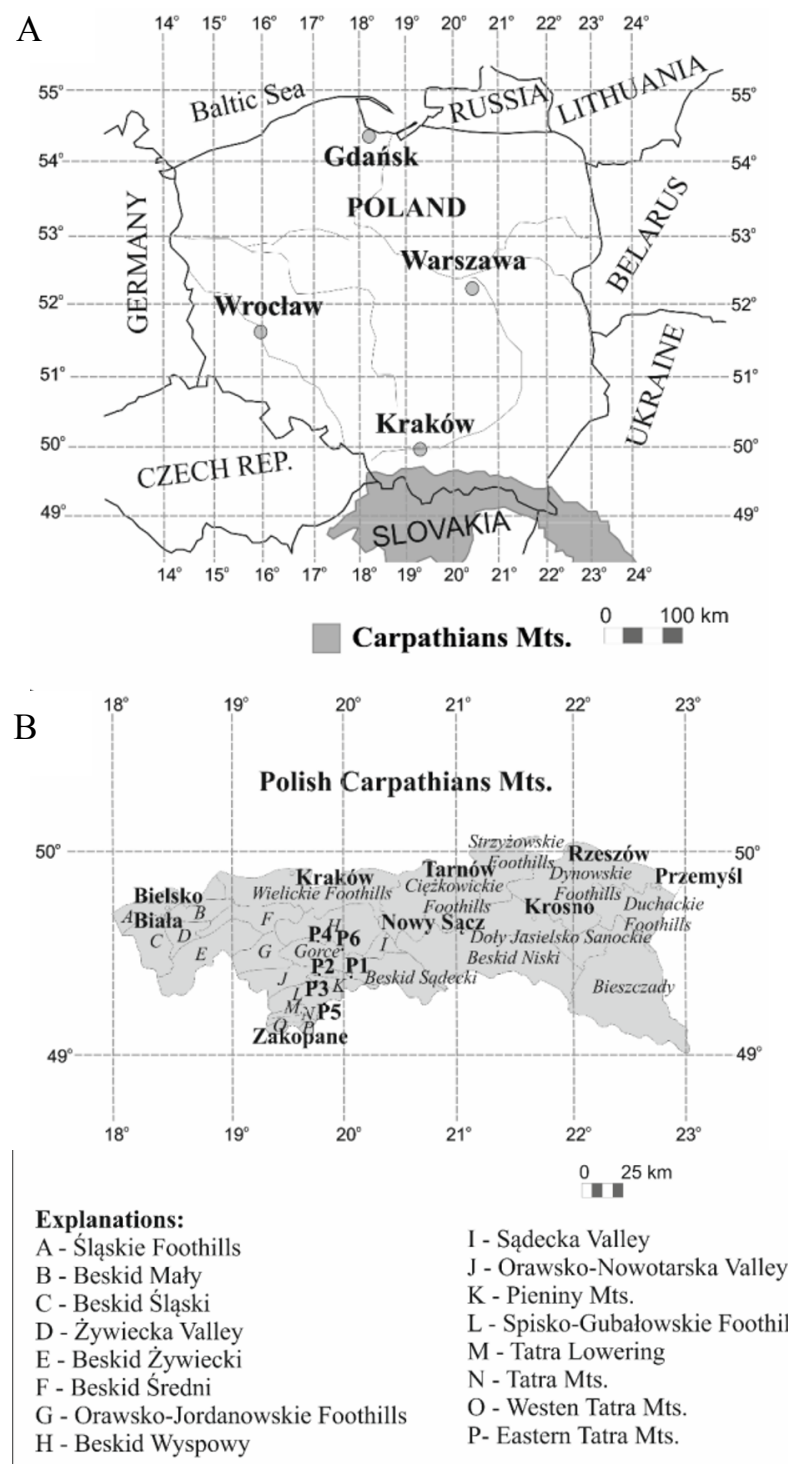

Figure 1 Location of soil profiles ( $\left.\mathrm{P}_{1}, \mathrm{P}_{2}, \mathrm{P}_{3}, \mathrm{P}_{4}, \mathrm{P}_{5}, \mathrm{P} 6\right)$ within the Polish Carpathians.

The soil cover of the Carpathians is very diverse. Moreover, soil zonality may often be noted, which is the result of varied geology, relief, climate and vegetation (Skiba 1995). The role of relief in the formation of soil cover is evident in the area, as morphology is very diverse. The dominant soil unit, mainly within the Beskidy Mts., is the Dystric/Eutric Cambisols, which often have developed from poorly permeable loamy-clayish flysch rocks. Further, within the Tatra Mts., Haplic/Orthic Podzols have developed on coarse-fragment and sandy-loam parent materials. Within the Pieniny Mts, and part of the Tatra Mts, Leptosols have formed on the carbonate-rich parent materials. The area of the Carpathian Foothills is characterized by silt-rich parent material, within which Luvisols and Stagnic Luvisols have developed. Some areas in the upper mountain floors are occupied by Regosols. Finally, Gleysols and Histosols may be recognized in small areas of the Carpathians and are mostly characterized by considerable fragmentation (Skiba 1995).

The Western Carpathians Mts. are characterized by mean annual air temperature ranges between $6^{\circ} \mathrm{C}$ and $8^{\circ} \mathrm{C}$ at $700 \mathrm{~m}$ a.s.l. and $4^{\circ} \mathrm{C}$ and $6^{\circ} \mathrm{C}$ at $1100 \mathrm{~m}$ a.s.l. At the highest elevations, the air temperature is usually between $2^{\circ} \mathrm{C}$ and $4^{\circ} \mathrm{C}$ (Otrębska-Starklowa et al. 1995). Mean annual precipitation varies between 400 and $900 \mathrm{~mm}$. The duration of snow cover reaches about 120 days per year on the highest peaks (OtrębskaStarklowa et al. 1995).

The vegetation at the sampling sites is dominated by semi-deciduous forest, deciduous forest and short grassland, characteristic of the lower montane zone (Towpasz and Zemanek 1995), which include the Dentario glandulosae-Fagetum, dominated by Fagus sylvatica, Abies alba and Acer pseudoplatanus, and Plagiothecio-Piceetum tatricum plant communities (Towpasz and Zemanek 1995).

\section{Materials and Methods}

The study area covers the Carpathians Mts.: Western Beskidy Mts. (Outer Western Carpathians) - profiles $\mathrm{P}_{2}, \mathrm{P}_{3}, \mathrm{P}_{4}$ and P6; and Podhale (Inner Western Carpathians) - profiles $\mathrm{P}_{1}$ and $\mathrm{P}_{5}$ (Figure 1). The studied profiles have been selected as representative of the sedimentary portion of the Carpathians, where the geodynamics seemed to be advanced and high heterogeneity within soils was very likely.

\subsection{Field procedures}

Soil samples were collected from the six soil 
profiles (32 genetic horizons in total) for further physicochemical, mineralogical, micromorphological and geochemical analyses. The organic horizons were not taken into account. Soil profiles were designated based on geological maps (scale 1:50,000) as well as the GeoLog website. Soils were located within the different parts of the slopes at heights from 374 to $680 \mathrm{~m}$ a.s.l. During the terrain reconnaissance, attention was paid to allochthonous component verification as well as identification of calcium carbonate-rich parent material. The soils (Figure 2) were described according to the Guidelines for Soil Description (FAO 2006). Field soil descriptions included determination of soil colour in moist samples using Munsell Soil Colour Charts (1975). The detailed site characteristics are presented in Table 2. Further, the soil reference groups were established using the WRB classification system (IUSS Working Group WRB 2015) (Table 2).

\subsection{Grain size distribution}

Particle-size distribution was determined using the hydrometer-sieve method according to Polish Standards (PN-R-04032 1998). Based on the particle size distribution analysis, indices of lithic discontinuity - Uniformity Values ( $\mathrm{UV}_{1}$ and $\mathrm{UV}_{2}$ ) and Lithological Discontinuity Index (LDI and $\mathrm{LDI}_{2}$ ) - were calculated based on formulas given by Cremeens and Mokma (1986), IUSS Working Group (2015), Kowalska et al. (2016), and Schaetzl and Anderson (2005) (Appendix 1 ). The indices allowed comparison of the soil particle content between two directly adjacent horizons.

\subsection{Basic chemical soil analyses}

Soil $\mathrm{pH}$ was potentiometrically measured in a 1:2.5 (soil: distilled water) suspension. Total organic carbon (TOC) and total nitrogen (TN) were examined using Tiurin's method and the Kjeldahl method, respectively (Lityński et al. 1976). Calcium carbonate content was determined by the Scheibler value method (Lityński et al. 1976). Estimation of total potential acidity (TPA) was conducted in 0.5 $\mathrm{M}$ sodium acetate at $\mathrm{pH}$ 8.2, while the sum of exchangeable bases $\left(\mathrm{Ca}^{2+}, \mathrm{Mg}^{2+}, \mathrm{Na}^{+}\right.$and $\left.\mathrm{K}^{+}\right)$was conducted in $1 \mathrm{M}$ ammonium chloride at $\mathrm{pH}$ 7.0 (IUSS Working Group 2015) and analysed with an
ICP-OES Optima 7300 DV spectrometer at the Department of Agricultural and Environmental Chemistry, University of Agriculture, Kraków.

\subsection{Heavy mineral analyses}

The relative quantitative and qualitative content of heavy minerals was analysed in the soil fraction from 0.100 to $0.063 \mathrm{~mm}$ in following sequences of soil horizons (P1: Ahk1, ACk, $3 \mathrm{C}_{2}$; $\mathrm{P} 2$ : Ah1, 2BCk, 2BCkt2; P3: Ah, 2Btg1, 2BCtg; P4: Ap, 2Btg1, 3BCtg2; P5: Ap, Bt, 2C; P6: AB, Btg2, BCtg), which represent the upper, middle and lower part of soil profile from each of the six soils (eighteen samples in total). After sieving and separating the appropriate fraction, the soil material was washed with $10 \% \mathrm{HCl}$. Then, determination of heavy minerals content was conducted based on the separation method of Sha and Chappelle (1999), using a heavy liquid (sodium polytungstate) having a density of $2.97 \mathrm{~g} \cdot \mathrm{cm}^{-3}$. At least 300 separated and cleaned grains of heavy minerals were identified in each sample. Identification of heavy minerals was performed using the scanning electron microscope JEOL JSM5410 tungsten filament cathode. Identification of heavy minerals was obtained via Scanning Electron Microscopy / Energy Dispersive $\mathrm{X}$-Ray Spectroscopy (SEM-EDS) analysis at the Institute of Geological Sciences, Jagiellonian University, Kraków, Poland.

Due to the fact that identification of heavy minerals was performed using the SEM-EDS method on three-dimensional grains, the obtained chemical data were rather rough and mineral differentiation (especially for amphiboles) was extremely difficult. This is the main reason why the amphibole super-group minerals were divided only into three main groups similar in chemical composition and environment: Ortho-amphiboles, derived from a process of low-grade metamorphism; Na-amphiboles, resulting from medium to high-grade metamorphism; as well as Ca-amphiboles, formed in igneous environments.

\subsection{Geochemistry data analyses}

In order to identify the lithic discontinuity and detect the possible admixture of allochthonous material (aeolian silt), geochemical analyses of major oxides as well as $\mathrm{Hf}$ and $\mathrm{Zr}$ in selected soil 

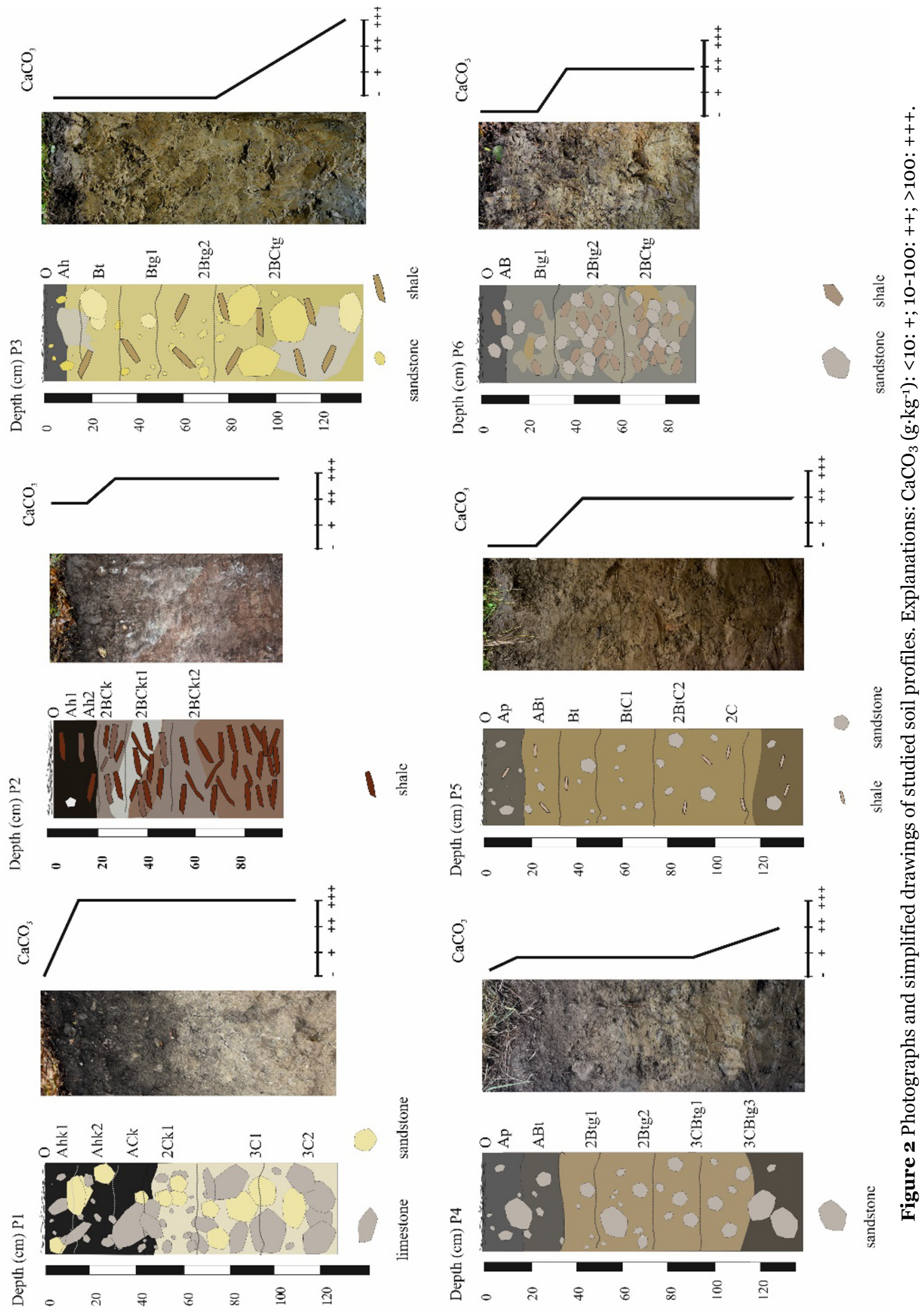
Table 2 Location site and general information of the studied soil profiles.

\begin{tabular}{|c|c|c|c|c|c|c|c|}
\hline $\begin{array}{l}\text { Soil } \\
\text { profile }\end{array}$ & $\begin{array}{l}\text { GPS position/ } \\
\text { Slope Rating/ } \\
\text { Elevation a. s. l. }\end{array}$ & $\begin{array}{l}\text { Landform } \\
\text { and } \\
\text { topography* }\end{array}$ & Place & $\begin{array}{l}\text { Geological } \\
\text { time }\end{array}$ & Parent material & $\begin{array}{l}\text { Vegetation } \\
* *\end{array}$ & $\begin{array}{l}\text { WRB classification } \\
\text { (IUSS, Working Group } \\
\text { 2015) }\end{array}$ \\
\hline P1 & $\begin{array}{l}49^{\circ} 25^{\prime} 26.6^{\prime \prime} \mathrm{N} \\
20^{\circ} 29^{\prime} \mathrm{o} 8.5^{\prime \prime} \mathrm{E} \\
12^{\circ}-15^{\circ} \mathrm{N} \\
664 \text { m a.s. l. }\end{array}$ & S, MS & $\begin{array}{l}\text { Tylka } \\
\text { village }\end{array}$ & $\begin{array}{l}\text { Jurassic, } \\
\text { Cretaceous }\end{array}$ & $\begin{array}{l}\text { Limestones and } \\
\text { sandstones } \\
\text { colluvium }\end{array}$ & FD & $\begin{array}{l}\text { Skeletic Calcisol } \\
\text { (Amphiloamic, Ochric, } \\
\text { Raptic) }\end{array}$ \\
\hline $\mathrm{P} 2$ & $\begin{array}{l}49^{\circ} 25^{\prime} 11.13^{\prime \prime N} \\
20^{\circ} 21^{\prime} 47.59^{\prime \prime} \mathrm{E} \\
3^{\circ} \mathrm{SEE} \\
680 \mathrm{~m} \text { a. s. } 1 .\end{array}$ & S, UP & $\begin{array}{l}\text { Hałuszow } \\
\text { a village }\end{array}$ & $\begin{array}{l}\text { Jurassic, } \\
\text { Cretaceous, } \\
\text { Paleocen }\end{array}$ & $\begin{array}{l}\text { Varied shales } \\
\text { with interbeds } \\
\text { of calcite veins } \\
\text { colluvium }\end{array}$ & FD & $\begin{array}{l}\text { Skeletic Regosol } \\
\text { (Endosiltic, Epiloamic, } \\
\text { Colluvic, Raptic) }\end{array}$ \\
\hline $\mathrm{P}_{3}$ & $\begin{array}{l}49^{\circ} 25^{\prime} 45.8^{\prime \prime} \mathrm{N} \\
20^{\circ} 20^{\prime} \mathrm{o} \cdot \mathrm{o}^{\prime \prime} \mathrm{E} \\
7^{\circ} \mathrm{SSW} \\
670 \mathrm{~m} \text { a. s. l. }\end{array}$ & $\mathrm{S}, \mathrm{CR}$ & $\begin{array}{l}\text { Majerz } \\
\text { glade }\end{array}$ & $\begin{array}{l}\text { Jurassic, } \\
\text { Cretaceous }\end{array}$ & $\begin{array}{l}\text { Sandstone and } \\
\text { shale colluvium }\end{array}$ & $\mathrm{HM}$ & $\begin{array}{l}\text { Stagnic Endocalcaric } \\
\text { Luvisol (Lomic, } \\
\text { Colluvic, Cutanic, } \\
\text { Ochric, Raptic) }\end{array}$ \\
\hline $\mathrm{P}_{4}$ & $\begin{array}{l}49^{\circ} 38^{\prime} 44 \cdot 3^{\prime \prime N} \\
19^{\circ} 58^{\prime} \mathrm{o} 5 \cdot 9^{\prime \prime} \mathrm{E} \\
15^{\circ} \mathrm{NE} \\
55^{1} \mathrm{~m} \text { a. s. } 1 .\end{array}$ & S, MS & $\begin{array}{l}\text { Lubień } \\
\text { village }\end{array}$ & Eocene & $\begin{array}{l}\text { Sandstone } \\
\text { colluvium }\end{array}$ & FS & $\begin{array}{l}\text { Luvic Calcaric Eutric, } \\
\text { Stagnosol (Episiltic, } \\
\text { Amphiloamic, Colluvic, } \\
\text { Ochric, Raptic) }\end{array}$ \\
\hline $\mathrm{P}_{5}$ & $\begin{array}{l}49^{\circ} 38^{\prime} 44 \cdot 3^{\prime \prime N} \\
19^{\circ} 58^{\prime} \mathrm{o} 5 \cdot 9^{\prime \prime} \mathrm{E} \\
15^{\circ} \mathrm{NE} \\
551 \mathrm{~m} \text { a. s. l. }\end{array}$ & S, UP & $\begin{array}{l}\text { Kacwin } \\
\text { village }\end{array}$ & $\begin{array}{l}\text { Eocene, } \\
\text { Oligocene }\end{array}$ & $\begin{array}{l}\text { Shale and } \\
\text { sandstone } \\
\text { colluvium }\end{array}$ & HS & $\begin{array}{l}\text { Calcaric, Eutric } \\
\text { Cambisol (Geoabruptic, } \\
\text { Episiltic, Amphiloamic, } \\
\text { Ochric, Raptic) }\end{array}$ \\
\hline P6 & $\begin{array}{l}49^{\circ} 46^{\prime} 38.3^{\prime \prime} \mathrm{N} \\
20^{\circ} 20^{\prime} 15.2^{\prime \prime} \mathrm{E} \\
10^{\circ} \mathrm{W} \\
474 \text { m a.s. } 1 .\end{array}$ & S, MS & $\begin{array}{l}\text { Niskowa } \\
\text { village }\end{array}$ & Miocene & $\begin{array}{l}\text { Sandstone and } \\
\text { shale colluvium }\end{array}$ & FS & $\begin{array}{l}\text { Eutric Calcaric } \\
\text { Stagnosol (Episiltic, } \\
\text { Amphiloamic, Colluvic, } \\
\text { Ochric, Skeletfic) }\end{array}$ \\
\hline
\end{tabular}

Explanation: Landform and topography*: S - sloping land; CR - crest; UP - upper slope; MS - middle slope;

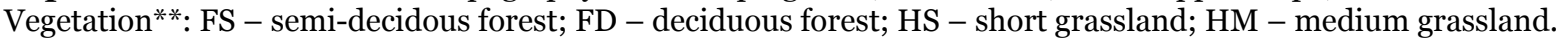

samples were performed using ICP-ES and ICP-MS after sample fusion with lithium borate and an alloy dissolution with nitric acid (ACME Labs - a Bureau Veritas Group Company, Canada). Harker diagrams were developed to concisely display the variations in major oxide concentrations with respect to changes in $\mathrm{SiO}_{2}$.

\subsection{Micromorphological soil characteristics}

Determination of the micromorphological features of the studied soils was based on thin sections from undisturbed soil material prepared with a 'Kubiena box'. Sampled soil material with undisturbed structure was consolidated in an Epovac vacuum chamber and impregnated using an epoxy resin, Araldite ${ }^{\circledR}$ 2020, or a polyester resin, Polimal ${ }^{\circledR}$ 108. Thin sections were prepared by a CS30 saw for soil sample cutting (Struers ${ }^{\circledR}$ ), the CL50 apparatus for precision lapping of thin sections (Logitech ${ }^{\circledR}$ ), as well as a CL5O apparatus for thin-section polishing (Logitech ${ }^{\circledR}$ ) located at the Institute of Soil Science and Soil Protection of Agriculture University in Kraków. Microscopic observations of thin sections used a Nikon Eclipse
400 microscope, under both plane- and crosspolarized light. Each thin section was described in accord with the nomenclature proposed by Stoops (2003).

\section{Results}

\subsection{Field soil characteristics}

Using the WRB classification (IUSS Working Group WRB 2015), the sampled soils were classified as Phaeozem, Regosol, Luvisol, Stagnosol or Cambosol with various principal and supplementary qualifiers (Table 2). The parent material consisted of sedimentary rocks enriched with calcium carbonate, such as limestone, sandstone and shale colluvia (Table 2; Figure 2). Among the rock coarse fragments, angular and subangular shapes prevailed. In general, the content of rock fragments increased down the soil profile. In soil $\mathrm{P} 1$, the rock content reached $85 \%$ in subangular shapes prevailed. In general, the content of rock fragments increased down the soil profile. In soil $\mathrm{P} 1$, the rock content reached $85 \%$ in 
the lowest horizon (Table 3). In soils $\mathrm{P}_{3}$ and $\mathrm{P}_{4}$, the content of rock fragments increased down the soil profile but was still quite low (reaching 30\%). Soil $\mathrm{P}_{5}$ had a homogenous rock fragment content of about $5 \%$ (Table 3). The distribution of rock fragments in P2 and P6 was various (from $5 \%$ to $65 \%$ and from $15 \%$ to $60 \%$ for $\mathrm{P} 2$ and $\mathrm{P} 6$, respectively), but generally increased in the middle part of the soil and then decreased again (Table 3).

\subsection{Grain size distribution}

The texture in the Ahk1 and Ahk2 of soil P1 was sandy loam with a considerably higher proportion of the sand over the clay fraction (Appendix 2; Figure 3). In the middle and lower horizons, the content of sand and silt was rather aligned (from $29 \%$ to $48 \%$ and from $32 \%$ to $53 \%$, respectively, Appendix 2) and resulted in a loam and silt loam texture (Figure 3). A totally different texture was recognized in soil $\mathrm{P} 2$, where the silt fraction prevailed, ranging from $46 \%$ to $57 \%$ (Appendix 2). The horizons Ah1 and Ah2 in P2 were characterized by a silt clay loam texture, while the middle and lower horizons (horizons $2 \mathrm{BCk}$, 2BCkt1, 2BCkt2) had a clay loam texture (Figure 3). Similarly, the silt content predominated in all the profiles of $\mathrm{P}_{4}$ and $\mathrm{P}_{5}$ (Appendix 2). In both cases, a silty loam texture was recognized in the upper and middle horizon (Ap, ABT, 2Btga and 2Btg2 for P4, and $\mathrm{Ap}, \mathrm{ABt}, \mathrm{Bt}$, $\mathrm{BtCa}$ for $\mathrm{P}_{5}$ ). In the lower horizons of $\mathrm{P}_{4}\left({ }_{3} \mathrm{BCtg} 1\right.$ and $\left.{ }_{3} \mathrm{BCtg} 2\right)$ and $\mathrm{P}_{5}(2 \mathrm{BtC} 2$ and $2 \mathrm{C}$ ), a silt clay loam texture was noted. The texture in $\mathrm{P} 6$ seemed to be quite homogenous; similar to most of the studied profiles, the silt fraction prevailed (50\%-64\%, Appendix 2). The highest share of silt was detected in the $\mathrm{AB}$ horizon, where a silt loam texture fraction occurred (Figure 3). Below this, the content of clay significantly increased (from $17 \%$ to $36 \%)$. Although within the Ah horizon of soil $\mathrm{P}_{3}$ the clay fraction dominated (39\%), in the lower horizons, the silt fraction noticeably prevailed (from 47\% to 60\%; Appendix 2). Profile $\mathrm{P}_{3}$ was also characterized by the presence of the clay loam texture group at depths from o to $22 \mathrm{~cm}$. Below this, at depths from 22 to $75 \mathrm{~cm}$, the silt clay loam texture group was recognized. The lowest horizon(2BCtg) had a silt loam texture (Figure 3).
P 1

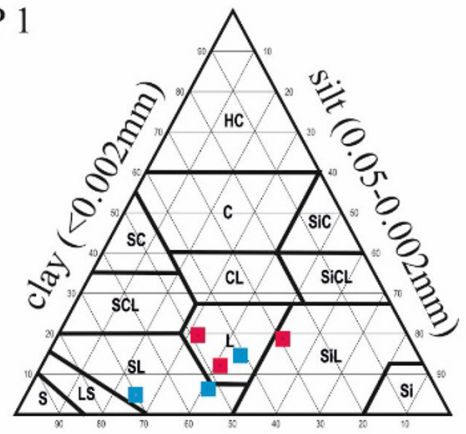

sand $(2-0.05 \mathrm{~mm})$

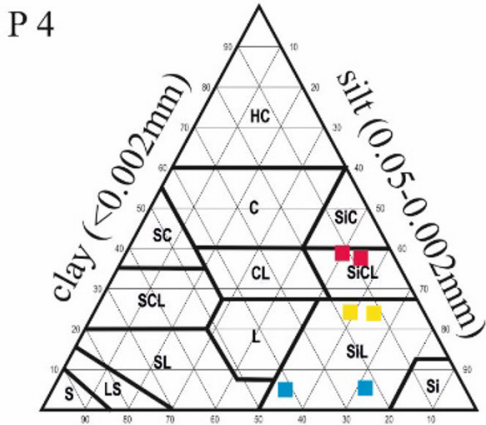

sand $(2-0.05 \mathrm{~mm})$

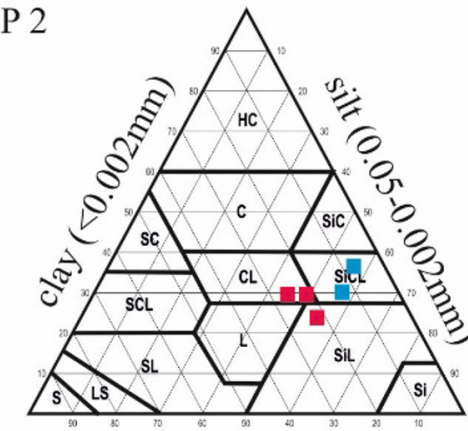

sand $(2-0.05 \mathrm{~mm})$

P 5

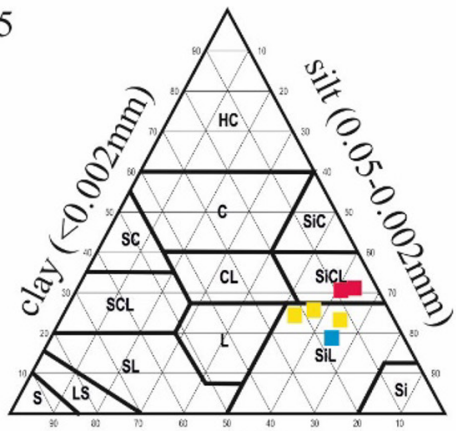

sand $(2-0.05 \mathrm{~mm})$

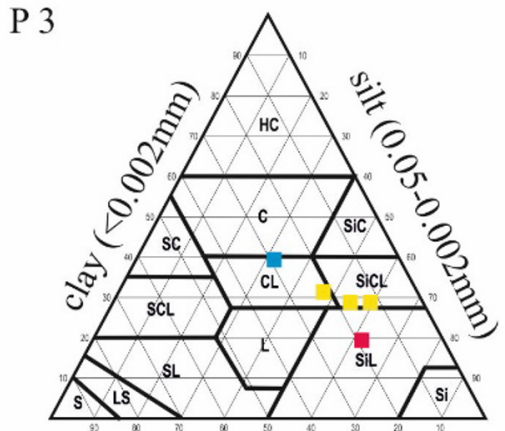

sand $(2-0.05 \mathrm{~mm})$

P 6

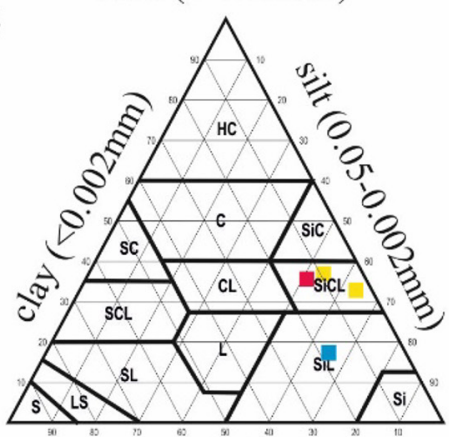

sand $(2-0.05 \mathrm{~mm})$

Explanation: A horizons B horizons $\mathrm{B} / \mathrm{C}$ or $\mathrm{C}$ horizons

Figure 3 Ferret's Triangle for particle sized distribution of studied soils. P1, P2, P3, P4, P5, P6 - the studied soil profiles. HC - heavy clay, C - clay, SC - sandy clay, SiC - silty clay, CL - clay loam, SCL - sandy clay loam, SiCL silty clay loam, SL - sandy loam, L - loam, SiL - silty loam, LS - loamy sand, S - sand, Si - slit. 


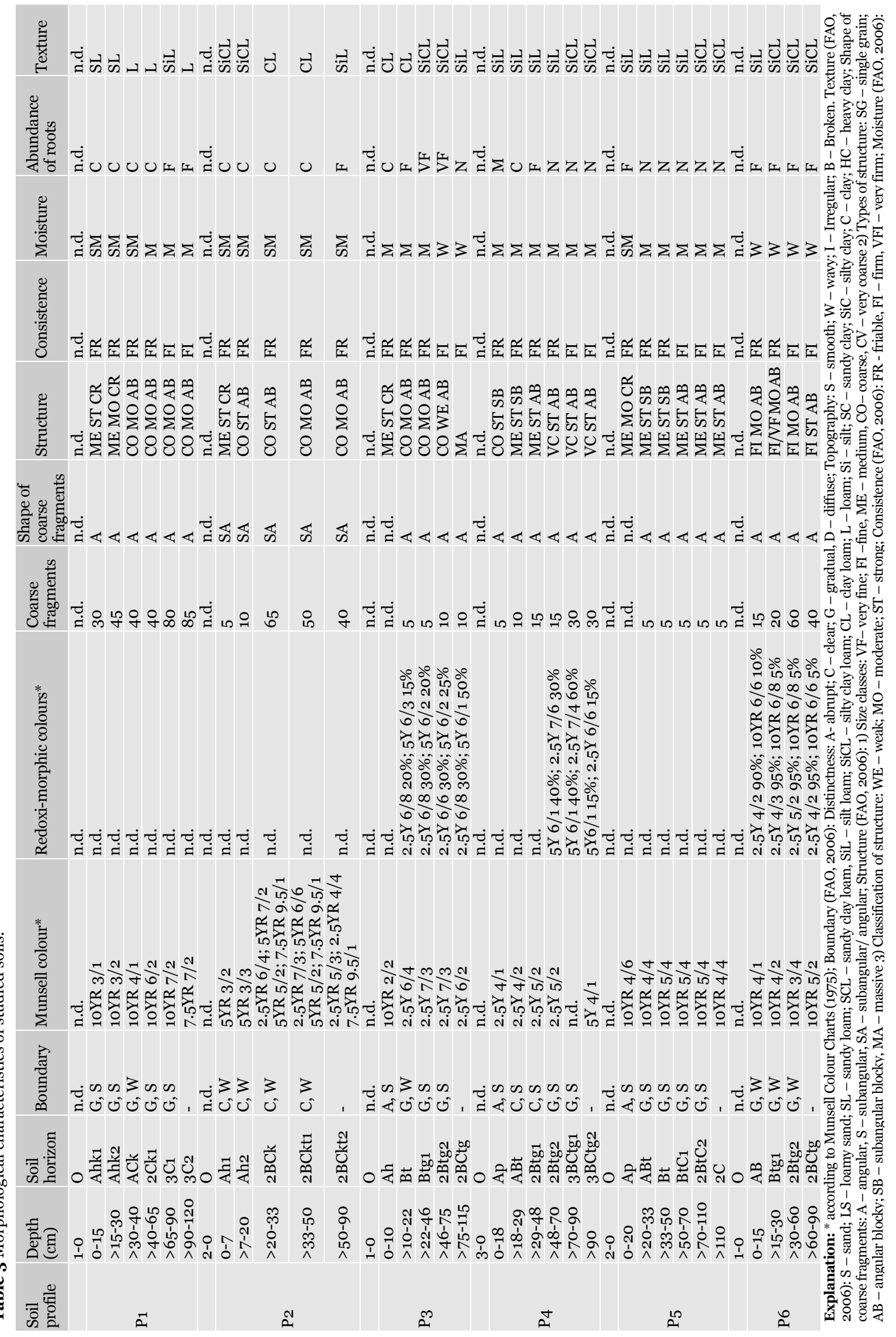




\subsection{Main chemical properties}

Most of the studied soils presented a neutral or alkaline reaction (Table 4). Only soils $\mathrm{P}_{4}$ and $\mathrm{P}_{5}$ had a slight acidic reaction. The $\mathrm{pH}$ values obtained were related to the occurrence of calcium carbonate. A very high content of calcium carbonate was noted in $\mathrm{P} 1$ and $\mathrm{P} 2$ (670 and $363 \mathrm{~g} \cdot \mathrm{kg}^{-1}$, respectively; Table 4). In profiles $\mathrm{P}_{4}, \mathrm{P}_{5}$ and $\mathrm{P} 6$, the content of calcium carbonate ranged between 2.20 and 37.4 $\mathrm{g} \cdot \mathrm{kg}^{-1}$, while soil $\mathrm{P}_{3}$ only presented calcium carbonate in the 2BCtg horizon (Table 4). The percent base saturation was related to $\mathrm{pH}$ and content of calcium carbonate; the highest base saturation was in $\mathrm{P} 1$ and $\mathrm{P} 2$. Slightly lower base saturations were obtained in soils $\mathrm{P}_{3}, \mathrm{P}_{4}$ and $\mathrm{P} 6$. Soil $\mathrm{P}_{5}$ showed the lowest values of base saturation (Table 4).

\subsection{Geochemistry data}

The content and distribution of the major oxides of studied soils unambiguously demonstrated a high heterogeneity, which could point to a different origin of individual soil layers/ horizons. Studied soils were generally characterized by a relatively high content of $\mathrm{SiO}_{2}$ and $\mathrm{Al}_{2} \mathrm{O}_{3}$, which ranged from $36.1 \%$ to $77.1 \%$ and

Table 4 Chemical properties of the studied soils.

\begin{tabular}{|c|c|c|c|c|c|c|c|c|c|c|c|c|c|c|c|c|}
\hline \multirow{3}{*}{ Soil profile } & \multirow{2}{*}{$\begin{array}{l}\text { Depth } \\
\text { (cm) }\end{array}$} & \multirow{2}{*}{$\begin{array}{l}\text { Soil } \\
\text { horizon }\end{array}$} & \multicolumn{2}{|l|}{ pH } & \multirow{2}{*}{\multicolumn{3}{|c|}{$\begin{array}{c}\mathrm{CaCO}_{3} \mathrm{TOC} \mathrm{TN} \\
\text { Unit: } \mathrm{g} \cdot \mathrm{kg}^{-1}\end{array}$}} & \multirow[t]{2}{*}{$\mathrm{C}: \mathrm{N}$} & $\mathrm{Ca}^{2+}$ & $\mathrm{Mg}^{2+}$ & $\mathrm{Na}^{+}$ & $\mathrm{K}^{+}$ & TEB & TPA & CEC & \multirow{2}{*}{$\begin{array}{l}\text { BS } \\
\%\end{array}$} \\
\hline & & & $\mathrm{H}_{2} \mathrm{O}$ & $\mathrm{KCl}$ & & & & & \multicolumn{7}{|c|}{ Unit: $\mathrm{mmol} \cdot \mathrm{kg}^{-1}$ of soil } & \\
\hline & $1-0$ & & n.d. & n.d. & n.d. & n.d. & n.d. & n.d. & n.d. & n.d. & n.d. & n.d. & n.d. & n.d. & n.d. & n.d. \\
\hline \multirow{7}{*}{ P1 } & $0-15$ & Ahk1 & 7.7 & 6.9 & 64.0 & 59.2 & 3.90 & 15.0 & 140 & 5.40 & 1.30 & 5.10 & 8.90 & 152 & 161 & 94 \\
\hline & $>15-30$ & Ahk2 & $7 \cdot 9$ & 7.2 & 148 & 26.7 & 1.70 & $15 \cdot 5$ & 106 & 14.1 & 1.50 & 5.80 & 7.10 & 127 & 135 & 95 \\
\hline & $>30-40$ & $\mathrm{ACk}$ & 8.2 & 7.2 & 360 & 13.2 & 1.80 & $7 \cdot 50$ & 131 & 3.00 & 1.00 & 5.10 & 5.40 & 140 & 145 & 96 \\
\hline & $>40-65$ & 2Ck1 & 8.2 & 7.6 & 670 & 11.6 & 1.00 & 11.7 & 103 & 3.20 & 0.80 & 2.90 & 4.50 & 110 & 115 & 96 \\
\hline & $>65-90$ & $3 \mathrm{C} 1$ & 8.6 & $7 \cdot 4$ & 349 & 9.30 & 0.80 & 11.4 & 131 & 4.00 & 1.00 & 3.50 & 8.00 & 140 & 148 & 95 \\
\hline & $>90-120$ & $3 \mathrm{C} 2$ & 8.5 & 7.4 & 247 & 8.60 & 0.70 & 11.6 & 187 & 6.40 & 1.10 & 8.60 & 3.60 & 203 & 206 & 98 \\
\hline & $2-0$ & $\mathrm{O}$ & n.d. & n.d. & n.d. & n.d. & n.d. & n.d. & n.d. & n.d. & n.d. & n.d. & n.d. & n.d. & n.d. & n.d. \\
\hline \multirow{6}{*}{$\mathrm{P} 2$} & $0-7$ & Ah1 & $7 \cdot 3$ & 6.5 & 28.0 & 89.0 & 4.90 & 18.1 & 157 & 6.00 & 1.50 & 5.20 & 8.00 & 170 & 178 & 95 \\
\hline & $>7-20$ & Ah2 & 8.2 & 6.8 & 94.0 & 39.5 & 2.40 & 16.7 & 189 & 6.70 & 1.50 & 4.40 & 8.00 & 201 & 209 & 96 \\
\hline & $>20-33$ & 2BCk & 8.8 & 7.1 & 363 & 16.7 & 0.60 & 29.0 & 141 & 21.2 & 2.50 & 6.50 & 5.40 & 171 & 177 & 97 \\
\hline & $>33-50$ & 2BCkt1 & 8.7 & $7 \cdot 3$ & 325 & 7.50 & 0.50 & $15 \cdot 3$ & 186 & 24.6 & 1.70 & 7.40 & 6.30 & 219 & 226 & 97 \\
\hline & $>50-90$ & 2BCkt2 & 8.6 & $7 \cdot 3$ & 260 & 5.70 & 0.50 & 12.8 & 120 & 20.8 & 1.60 & 7.20 & 7.10 & 150 & 157 & 96 \\
\hline & $1-0$ & $\mathrm{O}$ & n.d. & n.d. & n.d. & n.d. & n.d. & n.d. & n.d. & n.d. & n.d. & n.d. & n.d. & n.d. & n.d. & n.d. \\
\hline \multirow{6}{*}{$\mathrm{P}_{3}$} & $0-10$ & $\mathrm{Ah}$ & 6.2 & 5.1 & 0.00 & 18.5 & 4.30 & 4.40 & 219 & 21.1 & 1.60 & 4.70 & 247 & 54.5 & 301 & 82 \\
\hline & $>10-22$ & $\mathrm{Bt}$ & $7 \cdot 3$ & 4.5 & 0.00 & 2.70 & 0.60 & 4.40 & 156 & 25.0 & 2.10 & 5.20 & 188 & 26.8 & 215 & 88 \\
\hline & $>22-46$ & Btg1 & 8.2 & 6.0 & 0.00 & 2.30 & 0.50 & 4.50 & 159 & 25.0 & 2.20 & 4.80 & 191 & 14.3 & 205 & 93 \\
\hline & $>46-75$ & 2Btg2 & 8.3 & 6.4 & 0.00 & 1.10 & 0.60 & 1.70 & 191 & 30.0 & 2.10 & 5.60 & 229 & 9.80 & 239 & 96 \\
\hline & $>75^{-115}$ & 2BCtg & 8.8 & 7.4 & 113 & 0.60 & 0.40 & 1.60 & 156 & 20.9 & 1.50 & 7.20 & 186 & 6.30 & 192 & 97 \\
\hline & $3-0$ & $\mathrm{O}$ & n.d. & n.d. & n.d. & n.d. & n.d. & n.d. & n.d. & n.d. & n.d. & n.d. & n.d. & n.d. & n.d. & n.d. \\
\hline \multirow{7}{*}{$\mathrm{P}_{4}$} & $0-18$ & Ap & 6.1 & 5.1 & 0.00 & 25.9 & 1.80 & 14.2 & 43.6 & 13.9 & 0.90 & 1.60 & 59.9 & 42.9 & 102 & 58 \\
\hline & $>18-29$ & $\mathrm{ABt}$ & 6.1 & 5.2 & 2.20 & 8.70 & 0.60 & 14.1 & 35.8 & 10.8 & 0.80 & 1.60 & 49.0 & 24.3 & $73 \cdot 3$ & 67 \\
\hline & $>29-48$ & 2Btg1 & 6.4 & 5.4 & 2.50 & 7.40 & 0.70 & 10.0 & 56.8 & 15.8 & 1.00 & 1.40 & 75.1 & $24 \cdot 3$ & 99.3 & 76 \\
\hline & $>48-70$ & 2Btg2 & 6.6 & 5.6 & 3.10 & 6.20 & 0.00 & 0.00 & 44.0 & 11.8 & 0.90 & 1.20 & 57.9 & 22.4 & 80.3 & 72 \\
\hline & $70-90$ & 3BCtg1 & 7.6 & 6.6 & 6.80 & 7.00 & 0.00 & 0.00 & 87.8 & 19.9 & 0.90 & 2.10 & 110 & 7.50 & 118 & 94 \\
\hline & $>90$ & 3BCtg2 & 8.0 & 7.2 & 37.4 & 5.90 & 0.00 & 0.00 & 137 & 26.2 & 0.90 & 1.70 & 166 & 3.70 & 170 & 98 \\
\hline & $2-0$ & $\mathrm{O}$ & n.d. & n.d. & n.d. & n.d. & n.d. & n.d. & n.d. & n.d. & n.d. & n.d. & n.d. & n.d. & n.d. & n.d. \\
\hline \multirow{7}{*}{$\mathrm{P}_{5}$} & $0-20$ & Ap & 5.9 & 4.4 & 0.00 & 28.0 & 3.50 & 8.10 & 63.7 & 14.2 & 1.00 & 1.90 & 80.8 & 95.2 & 175 & 46 \\
\hline & $>20-33$ & $\mathrm{ABt}$ & 6.6 & $4 \cdot 3$ & 0.00 & 10.6 & 1.50 & 7.20 & 59.4 & 12.0 & 1.10 & 1.90 & 74.4 & 59.7 & 134 & 55 \\
\hline & $>33-50$ & Bt & 6.4 & 4.2 & 17.0 & 5.00 & 1.20 & 4.10 & 40.4 & 10.4 & 1.00 & 1.40 & 53.2 & 54.1 & 107 & 50 \\
\hline & $>50-70$ & BtC1 & 6.2 & 3.9 & 14.3 & 4.20 & 1.20 & 3.40 & 40.4 & 13.2 & 1.00 & 2.20 & 56.8 & 54.1 & 110 & 51 \\
\hline & $>70-110$ & 2BtC2 & 6.2 & 3.8 & 12.6 & 3.10 & 0.80 & 3.70 & 34.2 & 13.9 & 1.10 & 2.00 & 51.3 & 59.7 & 111 & 46 \\
\hline & $>110$ & $2 \mathrm{C}$ & 6.2 & 3.8 & 16.7 & 4.20 & 1.10 & 3.60 & 42.3 & 16.0 & 1.10 & 1.70 & 61.1 & $65 \cdot 3$ & 126 & 48 \\
\hline & $1-0$ & $\mathrm{O}$ & n.d. & n.d. & n.d. & n.d. & n.d. & n.d. & n.d. & n.d. & n.d. & n.d. & n.d. & n.d. & n.d. & n.d. \\
\hline \multirow{4}{*}{ P6 } & 0-15 & $\mathrm{AB}$ & $7 \cdot 9$ & $7 \cdot 3$ & 0.00 & 18.7 & 1.80 & 10.3 & 69.8 & 15.9 & 1.20 & 2.50 & 89.3 & 20.8 & 110 & 81 \\
\hline & $>15-30$ & Btg1 & 8.0 & 7.5 & 0.00 & 0.90 & 1.50 & 0.60 & 130 & 27.3 & 1.10 & 2.00 & 161 & 12.5 & 173 & 93 \\
\hline & $>30-60$ & 2Btg2 & 8.2 & $7 \cdot 5$ & 31.2 & 5.20 & 1.10 & 4.70 & 71.6 & 19.3 & 1.20 & 2.20 & 94.4 & 8.30 & 102 & 92 \\
\hline & $>60-90$ & 2BCtg & 8.4 & 7.6 & 34.9 & 3.00 & 0.60 & 5.00 & 156 & 28.8 & 1.40 & 2.40 & 188 & 4.20 & 193 & 98 \\
\hline
\end{tabular}

Explanations: TEB-total exchangeable bases; TPA- total potential acidity'; ECEC-cation exchange capacity; BS-base saturation; n.d.- not determined. 
from $7.08 \%$ to $18.6 \%$, respectively (Table 5). However, the highest values of $\mathrm{SiO}_{2}$ were seen in $\mathrm{P}_{3}, \mathrm{P}_{4}, \mathrm{P}_{5}$ and $\mathrm{P} 6$ profile, which could be the result of the significant content of quartz in those soils. Whereas, the highest contents of $\mathrm{Al}_{2} \mathrm{O}_{3}$, evidence of the occurrence of aluminosilicates in the parent materials of the soils, were noted in soils $\mathrm{P}_{5}$ and P6. Usually, no clear trend was recognized in case of these oxides; however, $\mathrm{P} 4$ and P6 showed an increasing content down the soil profile in the case of $\mathrm{Al}_{2} \mathrm{O}_{3}$ and an inverse relationship, i.e. a decrease with increasing depth, of $\mathrm{SiO} 2$ content.

Also, high contents were noted for $\mathrm{Fe}_{2} \mathrm{O}_{3}, \mathrm{MgO}$ and $\mathrm{CaO}$ (ranging from $1.4 \%-7.6 \%, 0.05 \%-0.24 \%$ and $0.23 \%-38.5 \%$, respectively), which may be connected with a significant percent content of phyllosilicates and amphiboles in the soils. The distribution of these oxides was very heterogenous, which reflected the various content and distribution of the respective minerals in soil profiles. The very high content of $\mathrm{CaO}$, especially in case of the middle and lower parts of P1 (from 16.9\% to $38.5 \%$ ) and $\mathrm{P} 2$ (from $15.0 \%$ to $21.5 \%$, Table 5) was connected with the abundance of calcium carbonate-rich coarse fragments. Similarly, oxides of the other major elements, i.e. $\mathrm{Na}_{2} \mathrm{O}, \mathrm{K}_{2} \mathrm{O}, \mathrm{P}_{2} \mathrm{O}_{5}$ and $\mathrm{MnO}$, showed very high heterogeneity and ranged from $0.28 \%$ to $1.16 \%$, from $0.72 \%$ to $3.48 \%$, from $0.06 \%$ to $0.2 \%$ and from $0.05 \%$ to $0.24 \%$, respectively (Table 5). Interestingly, there were significantly lower values of $\mathrm{Na}_{2} \mathrm{O}$ and $\mathrm{K}_{2} \mathrm{O}$ in $\mathrm{P} 1$ compared to other soils, whereas the contents of $\mathrm{P}_{2} \mathrm{O}_{5}$ and $\mathrm{MnO}$ were significantly higher, showing the highest values in profiles P1 and P2 (Table 5). This distribution of major oxides was probably due to the occurrence of a unique assemblage of minerals in this profile.

The values of $\mathrm{TiO}_{2}$ were also assessed, as this

Table 5 Major oxides and Hf and Zr content of studied soils.

\begin{tabular}{|c|c|c|c|c|c|c|c|c|c|c|c|c|c|c|}
\hline \multirow{2}{*}{ Soil } & \multirow{2}{*}{$\begin{array}{l}\text { Depth } \\
\text { (cm) }\end{array}$} & \multicolumn{11}{|c|}{ Content of major oxides (\%) } & \multicolumn{2}{|c|}{ Content $\left(\mathrm{mg} \cdot \mathrm{kg}^{-1}\right)$} \\
\hline & & $\mathrm{SiO}_{2}$ & $\mathrm{Al}_{2} \mathrm{O}_{3}$ & $\mathrm{Fe}_{2} \mathrm{O}_{3}$ & $\mathrm{MgO}$ & $\mathrm{CaO}$ & $\mathrm{CaO}^{*}$ & $\mathrm{Na}_{2} \mathrm{O}$ & $\mathrm{K}_{2} \mathrm{O}$ & $\mathrm{TiO}_{2}$ & $\mathrm{P}_{2} \mathrm{O}_{5}$ & $\mathrm{MnO}$ & $\mathrm{Hf}$ & $\mathrm{Zr}$ \\
\hline \multirow{6}{*}{ P1 } & $0-15$ & 59.3 & $9 \cdot 35$ & 3.72 & 1.19 & 5.24 & 0.064 & 0.77 & 1.68 & 0.48 & 0.15 & 0.09 & 4.4 & 173 \\
\hline & $>15-30$ & $57 \cdot 3$ & 8.29 & $3 \cdot 38$ & 1.19 & 11.2 & 0.148 & 0.78 & 1.55 & 0.41 & 0.12 & 0.08 & 4.5 & 173 \\
\hline & $>30-40$ & 38.6 & 7.08 & 2.72 & 0.96 & 22.8 & 0.360 & 0.53 & 1.31 & 0.36 & 0.18 & 0.12 & 3.4 & 121 \\
\hline & $>40-65$ & 19.4 & 3.67 & 1.40 & 0.60 & 38.5 & 0.670 & 0.28 & 0.72 & 0.19 & 0.12 & 0.05 & 1.8 & 72.2 \\
\hline & $>65-90$ & 44.6 & 7.76 & 3.03 & 1.02 & 19.9 & 0.349 & 0.61 & 1.58 & 0.45 & 0.15 & 0.12 & 5.0 & 196 \\
\hline & $>90-120$ & 49.6 & 8.22 & 3.29 & 1.17 & 16.9 & 0.247 & 0.69 & 1.69 & 0.45 & 0.14 & 0.11 & 5.1 & 192 \\
\hline \multirow{5}{*}{ P2 } & $2-7$ & 48.9 & 13.8 & 5.19 & 1.85 & 3.07 & 0.028 & 1.01 & 2.75 & 0.61 & 0.12 & 0.24 & 3.8 & 133 \\
\hline & $>7-20$ & 51.7 & 14.7 & 5.50 & 2.01 & 5.69 & 0.094 & 1.04 & 2.95 & 0.64 & 0.10 & 0.24 & 3.8 & 140 \\
\hline & $>20-33$ & 36.0 & 11.1 & 3.71 & 1.65 & 21.5 & 0.363 & 0.60 & 2.53 & 0.42 & 0.10 & 0.15 & 2.1 & 77.1 \\
\hline & $>33-50$ & 38.2 & 12.0 & 4.76 & 1.81 & 19.0 & 0.325 & 0.71 & 2.72 & 0.46 & 0.10 & 0.14 & 2.4 & 90.4 \\
\hline & $>50-90$ & 42.1 & 13.8 & 5.42 & 2.14 & 15.0 & 0.260 & 0.97 & 3.05 & 0.54 & 0.11 & 0.12 & 3.2 & 114 \\
\hline \multirow{5}{*}{$\mathrm{P}_{3}$} & $0-10$ & 63.2 & 10.3 & 3.72 & 0.95 & 0.89 & 0.000 & 0.96 & 1.81 & 0.70 & 0.13 & 0.07 & 8.3 & 324 \\
\hline & $>10-22$ & 69.0 & $13 \cdot 3$ & 4.96 & 1.25 & 0.57 & 0.000 & 1.01 & 2.47 & 0.79 & 0.07 & 0.08 & 9.0 & 347 \\
\hline & $>22-46$ & 69.9 & 12.9 & 4.78 & 1.21 & 0.60 & 0.000 & 1.03 & 2.38 & 0.80 & 0.09 & 0.05 & 9.1 & 350 \\
\hline & $>46-75$ & 70.0 & 13.0 & 4.79 & 1.23 & 0.61 & 0.000 & 1.02 & 2.42 & 0.83 & 0.09 & 0.05 & 9.0 & 345 \\
\hline & $>75-115$ & 63.1 & 10.4 & 3.69 & 1.64 & 7.13 & 0.113 & 0.97 & 2.29 & 0.68 & 0.11 & 0.06 & 9.4 & 358 \\
\hline \multirow{6}{*}{$\mathrm{P}_{4}$} & $0-18$ & 74.7 & 8.77 & 3.14 & 1.04 & 0.41 & 0.000 & 1.38 & 1.61 & 0.68 & 0.17 & 0.07 & 8.8 & 353 \\
\hline & $>18-29$ & 77.1 & 9.42 & 3.46 & 1.12 & 0.35 & 0.002 & 1.42 & 1.72 & 0.72 & 0.09 & 0.08 & 9.9 & 382 \\
\hline & $>29-48$ & 66.7 & 14.2 & 5.53 & 1.90 & 0.45 & 0.003 & 1.42 & 2.51 & 0.93 & 0.08 & 0.09 & $7 \cdot 4$ & 293 \\
\hline & $>48-70$ & 68.6 & 13.5 & 5.17 & 1.69 & 0.40 & 0.003 & 1.46 & 2.30 & 1.00 & 0.07 & 0.08 & 8.4 & 317 \\
\hline & $>70-90$ & $57 \cdot 3$ & 18.2 & 7.07 & 2.86 & 0.99 & 0.007 & 1.40 & 3.45 & 0.94 & 0.13 & 0.10 & 5.8 & 217 \\
\hline & $>90$ & 55.8 & 17.8 & 6.99 & 3.02 & 2.22 & 0.037 & 1.31 & 3.48 & 0.90 & 0.15 & 0.08 & $5 \cdot 3$ & 192 \\
\hline \multirow{6}{*}{$\mathrm{P}_{5}$} & $0-20$ & 55.8 & 16.0 & 6.78 & 1.64 & 0.46 & 0.000 & 0.93 & 2.87 & 0.92 & 0.20 & 0.09 & 4.6 & 135 \\
\hline & $>20-33$ & 58.8 & 17.1 & 7.15 & 1.65 & 0.41 & 0.000 & 0.93 & 3.00 & 0.98 & 0.12 & 0.11 & 4.8 & 148 \\
\hline & $>33-50$ & 61.7 & 16.4 & 7.09 & 1.71 & 0.27 & 0.005 & 0.99 & 2.94 & 0.99 & 0.08 & 0.07 & 5.2 & 136 \\
\hline & $>50-70$ & 58.6 & 18.2 & $7 \cdot 55$ & 1.93 & 0.26 & 0.005 & 0.89 & 3.38 & 0.95 & 0.06 & 0.06 & 4.7 & 150 \\
\hline & $>70-110$ & 60.0 & 17.5 & 7.43 & 1.87 & 0.23 & 0.003 & 0.94 & 3.25 & 0.97 & 0.07 & 0.07 & 5.1 & 144 \\
\hline & $>110$ & 57.9 & 18.6 & 7.69 & 2.00 & 0.26 & 0.006 & 0.87 & 3.46 & 0.96 & 0.08 & 0.06 & 4.5 & 157 \\
\hline \multirow{4}{*}{ P6 } & $0-15$ & $65 \cdot 3$ & 12.8 & 4.56 & 1.38 & 0.93 & 0.000 & 1.12 & 2.72 & 0.77 & 0.10 & 0.09 & 9.9 & 382 \\
\hline & $>15-30$ & 64.4 & 14.4 & 5.20 & 1.70 & 1.23 & 0.000 & 1.14 & 2.98 & 0.81 & 0.10 & 0.10 & 9.7 & 362 \\
\hline & $>30-60$ & 59.1 & 16.3 & 5.91 & 2.14 & 2.48 & 0.031 & 1.19 & 3.26 & 0.82 & 0.10 & 0.13 & 6.2 & 234 \\
\hline & $>60-90$ & 58.4 & 16.5 & 5.90 & 2.45 & 2.62 & 0.035 & 1.19 & $3 \cdot 33$ & 0.83 & 0.11 & 0.08 & 5.5 & 220 \\
\hline
\end{tabular}

Explanations: $\mathrm{CaO}^{*}-\mathrm{mol} \mathrm{CaO}($ wt\% $\mathrm{CaO} / 56.077)-$ mol $\mathrm{CaCO}_{3}\left(\mathrm{wt} \% \mathrm{CaCO}_{3} / 100,086\right)$ according to Fedo et al. 2013 . 
oxide is considered resistant to weathering and could be used as a lithic discontinuity indicator. However, these oxides were been distributed very randomly and ranged from $0.19 \%$ to $1.00 \%$, and thus did not unambiguously indicate the lithic discontinuity boundary in the studied soils. Moreover, the values of $\mathrm{TiO}_{2}$ did not show higher values in the upper horizons. The highest values of $\mathrm{TiO}_{2}$ were seen in profiles $\mathrm{P}_{3}, \mathrm{P}_{4}, \mathrm{P}_{5}$ and $\mathrm{P} 6$, however these still indicated high stratification.

$\mathrm{Zr}$ and $\mathrm{Hf}$ values are widely used as an indicator of allochthonous silt admixture (Loba et al. 2019; Schreib et al. 2010; 2014; Waroszewski et al. 2018a, 2018b, 2019). According to these authors, aeolian silt contribution is characterized by values ranging from 237 to $453 \mathrm{mg} \cdot \mathrm{kg}^{-1}$ and from 8 to 14 $\mathrm{mg} \cdot \mathrm{kg}^{-1}$ for $\mathrm{Zr}$ and $\mathrm{Hf}$, respectively. Some of the studied soils ( $\mathrm{P}_{3}, \mathrm{P}_{4}$ and $\mathrm{P} 6$ ) showed a high content of $\mathrm{Zr}$ and $\mathrm{Hf}$, especially in the topsoil and middle parts of profiles and exceeded the values given in the literature. The values of $\mathrm{Zr}$ and $\mathrm{Hf}$ ranged from 8.3 to $9.4 \mathrm{mg} \cdot \mathrm{kg}^{-1}$ and from 324.4 to $358.5 \mathrm{mg} \cdot \mathrm{kg}^{-1}$ in whole profile $\mathrm{P}_{3}$; from 7.4 to 9.9 $\mathrm{ppm}$ and from 293.5 to $382.7 \mathrm{mg} \cdot \mathrm{kg}^{-1}$ in the upper and middle horizons of $\mathrm{P} 4$ and from 9.7 to 9.9 $\mathrm{mg} \cdot \mathrm{kg}^{-1}$ and 362.1 to $382.6 \mathrm{mg} \cdot \mathrm{kg}^{-1}$ in upper horizons of P6 (Table 5). This may indicate an aeolian silt addition to those soils.

\subsection{Heavy mineral content}

Among the heavy minerals, the amphiboles group predominated (Figure 4; Figure 5). The total percentage content of amphiboles ranged between 7.10\% (horizon $\mathrm{Bt}$ of $\mathrm{P}_{5}$ ) and $97.8 \%$ (horizon 2BCkt2 of P2). Generally, Ortho-amphiboles predominated and occurred in every studied soil horizon (Figure 4; Table 6), except horizon 2BCkt2 from P2, where more than $81.9 \%$ were Caamphiboles (Figure 4). Outside of soil $\mathrm{P} 4$, where the number of amphiboles decreased with depth, no clear trend for amphibole arrangements was noted. The highest diversity in terms of the origin of amphiboles was found in profile $\mathrm{P}_{3}$ (Btg1 horizon) as well as P1 (ACk horizon), P2 (2BCkt2 horizon) and $\mathrm{P} 6$ (AB horizon). Such variability may be mostly a result of a different lithology or possibility of allochthonous material incorporation.

Furthermore, the uppermost and middle horizons of $\mathrm{P}_{1}, \mathrm{P}_{3}$ and $\mathrm{P} 6$ (horizons Ahk1-ACk, Ah1-Btg and AB-Btg2, respectively) and the upper horizons of $\mathrm{P}_{2}$ and $\mathrm{P}_{5}$ (horizons $\mathrm{Ah} 1$ and $\mathrm{Ap}$, respectively) had an occurrence of epidote, suggesting an acid igneous environment of soil material (Figure 4; Figure 5) and might also evidence the admixture of allochthonous material.

Table 6 The percentage content of heavy minerals in studied soils.

\begin{tabular}{|c|c|c|c|c|c|c|c|c|c|c|c|c|c|}
\hline \multirow{4}{*}{$\begin{array}{l}\text { Soil } \\
\text { profile }\end{array}$} & \multirow{4}{*}{$\begin{array}{l}\text { Depth } \\
(\mathrm{cm})\end{array}$} & \multirow{4}{*}{$\begin{array}{l}\text { Soil } \\
\text { horizon }\end{array}$} & \multicolumn{11}{|c|}{ The percentage content of heavy minerals (\%) } \\
\hline & & & \multicolumn{3}{|c|}{ Amphiboles } & \multicolumn{2}{|c|}{ Epidote } & \multicolumn{2}{|c|}{ Garnet } & \multirow{3}{*}{$\begin{array}{l}\text { Zircon } \\
\text { IG }\end{array}$} & \multirow{3}{*}{$\begin{array}{l}\text { Pyrite } \\
\text { S D }\end{array}$} & \multirow{3}{*}{$\begin{array}{l}\text { TiOx } \\
\text { UN }\end{array}$} & \multirow{3}{*}{$\begin{array}{l}\text { Ilmenite } \\
\text { IG }\end{array}$} \\
\hline & & & H LM & HM & IG & IG & $\mathrm{HM}$ & IG & H LM & & & & \\
\hline & & & Ortho-Am & $\mathrm{Na}-\mathrm{Am}$ & Ca-Am & & Alm & Prp & Adr/Grs & & & & \\
\hline \multirow{3}{*}{$\mathrm{P} 1$} & $0-15$ & Ahk1 & 26.3 & 4.10 & 0.00 & 20.20 & 4.10 & 2.00 & 0.00 & 0.00 & 0.90 & 38.4 & 4.10 \\
\hline & $30-40$ & $\mathrm{ACk}$ & 32.3 & 2.70 & 5.40 & 2.70 & 8.10 & 0.00 & 0.00 & 5.80 & 0.00 & $37 \cdot 7$ & $5 \cdot 40$ \\
\hline & $90-120$ & $3 \mathrm{C} 2$ & 55.6 & 0.00 & 0.00 & 0.00 & 0.00 & 0.00 & 0.00 & 0.00 & 0.00 & 44.4 & 0.00 \\
\hline \multirow{3}{*}{ P2 } & $0-7$ & Ah1 & 52.0 & 0.00 & $7 \cdot 90$ & 4.50 & 7.80 & 0.00 & 8.09 & 3.80 & 0.00 & 12.4 & $3 \cdot 50$ \\
\hline & $20-33$ & 2BCk & 75.0 & 0.00 & 0.00 & 0.00 & 0.00 & 0.00 & 0.00 & 0.00 & 0.00 & 25.0 & 0.00 \\
\hline & $50-90$ & 2BCkt2 & 14.5 & 1.50 & 81.9 & 0.00 & 0.00 & 0.00 & 0.00 & 0.00 & 0.00 & 2.20 & 0.00 \\
\hline \multirow{3}{*}{ P3 } & $0-10$ & Ah & 54.9 & 0.00 & 3.90 & 3.90 & $3 \cdot 30$ & 0.00 & 3.87 & 13.70 & 0.00 & 16.5 & 0.00 \\
\hline & $22-46$ & Btg1 & 33.0 & 3.10 & 30.9 & 3.10 & 1.00 & 1.20 & 3.09 & 2.40 & 0.00 & 17.5 & 0.00 \\
\hline & $75-115$ & 2BCtg & 56.0 & 0.00 & 18.6 & 0.00 & 0.00 & 0.00 & 0.00 & 1.20 & 0.00 & 24.2 & 0.00 \\
\hline \multirow{3}{*}{$\mathrm{P}_{4}$} & $0-18$ & Ap & 50.0 & 0.00 & 0.00 & 0.00 & 10.6 & 0.00 & 0.00 & 9.60 & 0.00 & 29.9 & 0.00 \\
\hline & $29-48$ & 2Btg1 & 54.6 & 0.00 & 0.00 & 0.00 & 9.10 & 0.00 & 0.00 & 0.00 & 0.00 & 36.3 & 0.00 \\
\hline & $>90$ & 3BCtg2 & 70.0 & 0.00 & 0.00 & 0.00 & 0.00 & 9.70 & 0.00 & 0.00 & 0.00 & 20.3 & 0.00 \\
\hline \multirow{3}{*}{$\mathrm{P}_{5}$} & $0-20$ & Ap & 48.8 & 0.00 & 0.00 & 3.70 & 4.90 & 3.90 & 0.53 & 0.00 & 1.50 & 34.1 & 2.40 \\
\hline & $33-50$ & $\mathrm{Bt}$ & 7.10 & 0.00 & 0.00 & 0.00 & 0.00 & 0.00 & 0.00 & 0.00 & 1.60 & 90.0 & 1.30 \\
\hline & $>110$ & $2 \mathrm{C}$ & 68.4 & 0.00 & 0.00 & 0.00 & 0.00 & 0.00 & 0.00 & 0.00 & 1.20 & 30.4 & 0.00 \\
\hline \multirow{3}{*}{ P6 } & $0-15$ & $\mathrm{AB}$ & 16.1 & 6.40 & 5.90 & 10.20 & 5.10 & 0.00 & 10.10 & 0.00 & 0.70 & 42.3 & 3.40 \\
\hline & $15-30$ & Btg2 & $35 \cdot 9$ & 0.00 & 0.00 & 9.60 & 0.00 & 6.30 & 6.09 & 0.00 & 0.00 & 42.0 & 0.00 \\
\hline & $60-90$ & 2BCtg & 28.2 & 0.00 & 0.00 & 0.00 & 0.00 & 0.00 & 0.00 & 0.00 & 0.00 & 71.8 & 0.00 \\
\hline
\end{tabular}

Explanations: H LM - hydrothermal and low grade metamorphism; HM - high grade metamorphism; IG igneous; S - sedimentary, D - diagenetic; UN - undivided. 
A very high content of epidote was noted in the Ahk1 horizon of P1 (20.2\%; Table 6; Figure 4; Figure 5).

Minerals from the garnet group were present in most of the studied horizons (Figure 4; Figure 5). Garnet group minerals prevailed in the upper and middle horizons (Figure 4). The highest percentage values were noted in the Ah horizon of $\mathrm{P} 2$ (14.9\% in total, Table 6). Within the garnets, various origins were distinguished. Metamorphic (e.g. almandine, ranging from $1.0 \%$ in $\mathrm{Btg} 1, \mathrm{P}_{3}$ to $10.6 \%$ in $\mathrm{Ap}$, $\mathrm{P}_{4}$; Table 6) and alkaline igneous garnets (e.g. pyrope, ranging from $1.02 \%$ in $\mathrm{Btg}_{1}, \mathrm{P}_{3}$ to $9.7 \%$ in $3 \mathrm{BCtg} 2, \mathrm{P} 4$; Table 6) were dominant (Figure 5). However, transitional phases also presented lowgrade metamorphic and hydrothermal origins, such as andradite/ grossular (Figure 5).

The input of allochthonous material was also detected based on zircon occurrence, as it has a strictly acidic igneous and sedimentary origin (Figure 5). Zircon occurred in the topsoil of $\mathrm{P}_{2}, \mathrm{P}_{3}$ and $\mathrm{P}_{4}$ and ranged from $4.1 \%$ to $14.3 \%$ (Table 6). Furthermore, zircons also have been noted in the middle parts of some profiles, e.g. $\mathrm{P}_{1}$ and $\mathrm{P}_{3}$.

Framboid pyrite also occurred, characterized by strictly sedimentary origin (Figure 5). The arrangement of pyrite was rather random and occurred in both the upper horizon ( $\mathrm{P}_{1}$ and $\mathrm{P}_{5}$ ) as well as the whole profile $\left(\mathrm{P}_{5}\right)$ (Figure 4). However, the share of pyrite was rather minor (ranging from $0.8 \%$ to $1.6 \%$, Figure 4 ; Table 5).

The content of titanium oxide $\left(\mathrm{TiO}_{2}\right)$, derived from hydrothermal and/or igneous and/or metamorphic environment, was very common in every analysed soil horizon but the percentage content differed greatly from $2.2 \%$ to $90.0 \%$. Furthermore, a small amount of ilmenite - from $1.3 \%$ to $5.4 \%$ (surface and/or middle
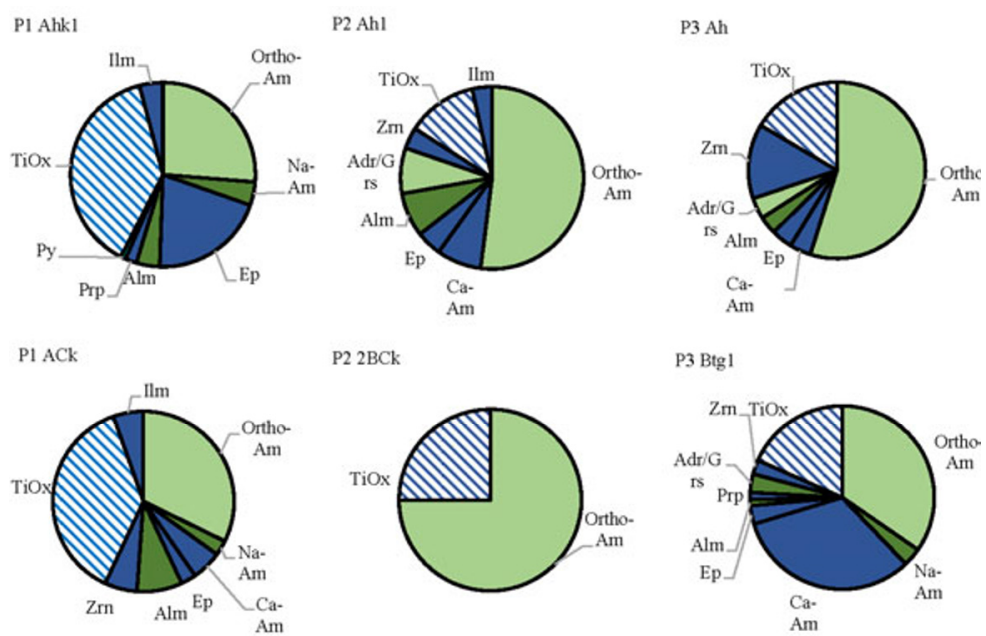

P2 2BCk
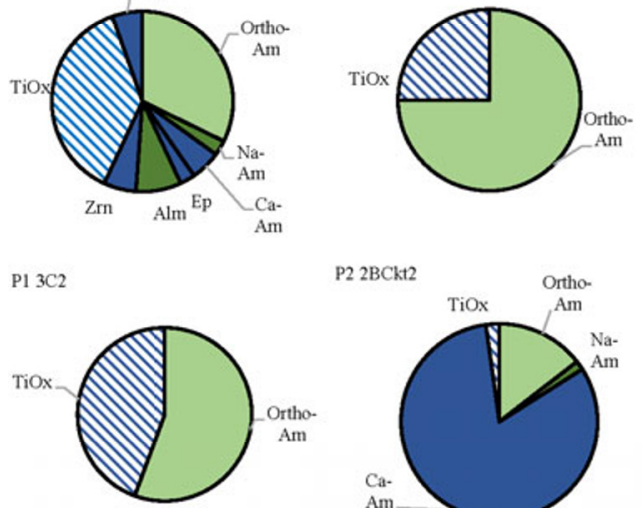

P3 Btg1
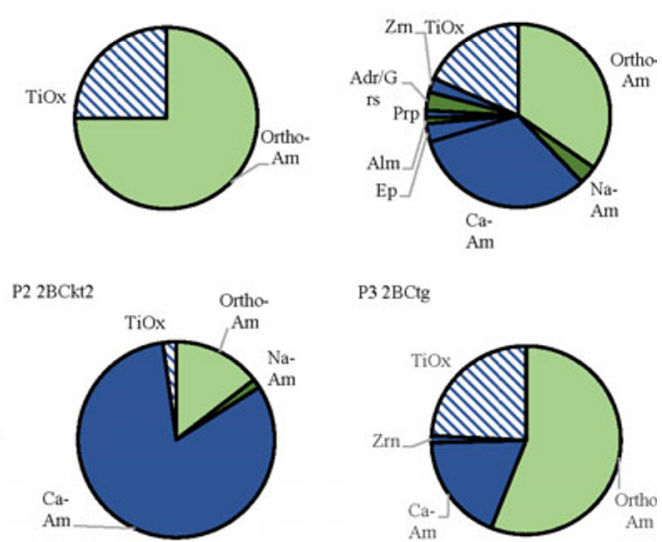

P3 2BCtg
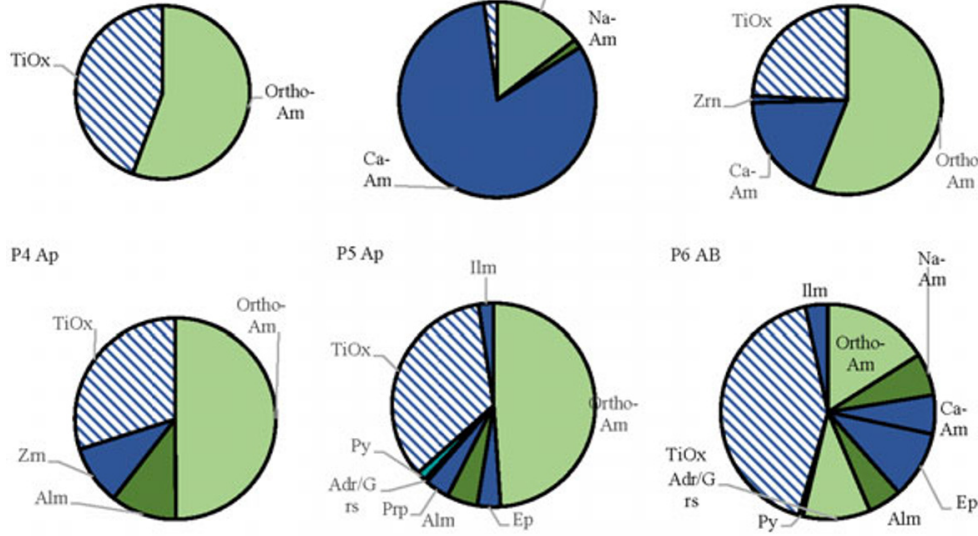

P4 2Btg1

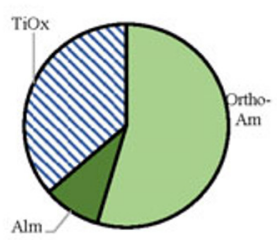

PS Bt
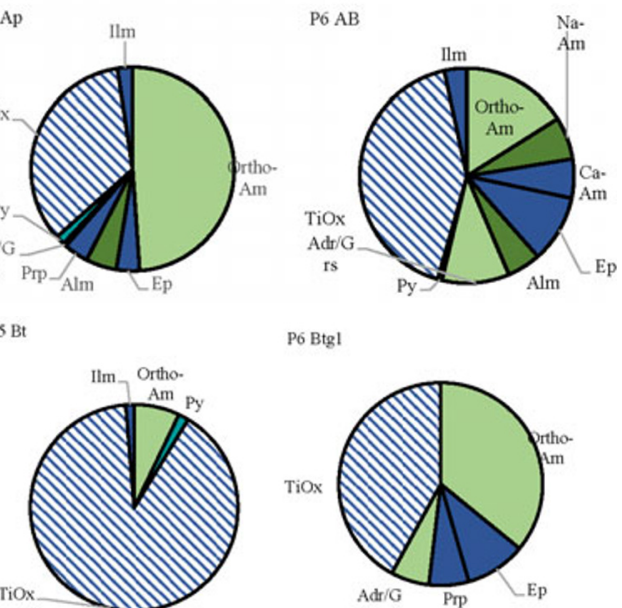

P6 Btgl
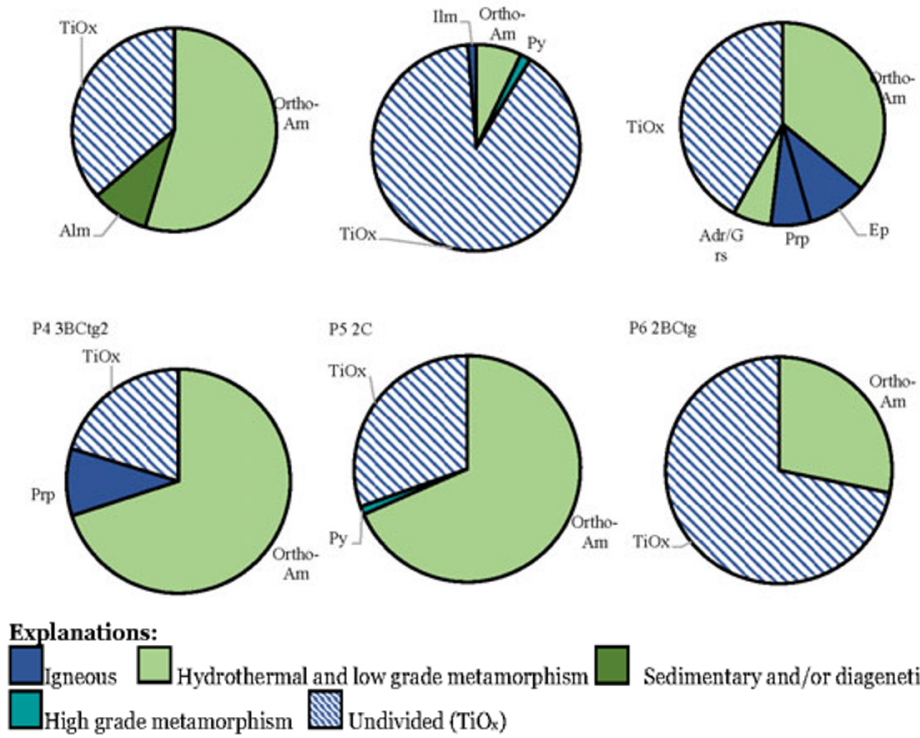

d low grade metamorphism

Sedimentary and/or diagenetic

Figure 4 Percentage content of heavy mineral in studied soil profiles. Explanations: Adr/Grs - Andradite/Grossular, Alm - Almandine, CaAm - Ca-Amphibole, Ep - Epidote, Ilm - Ilmenite, Na-Am - NaAmphibole, Ortho-Am - Ortho-Amphibole, Prp - Pyrope, Py - Pyrite, TiOx - titanium oxide, Zrn - Zircon.. 

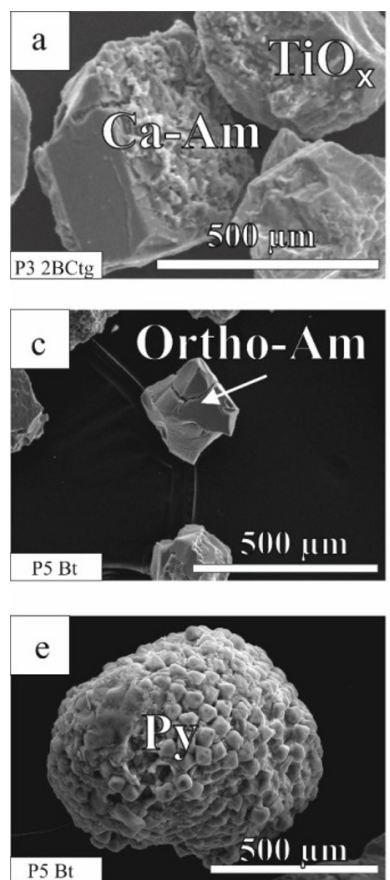
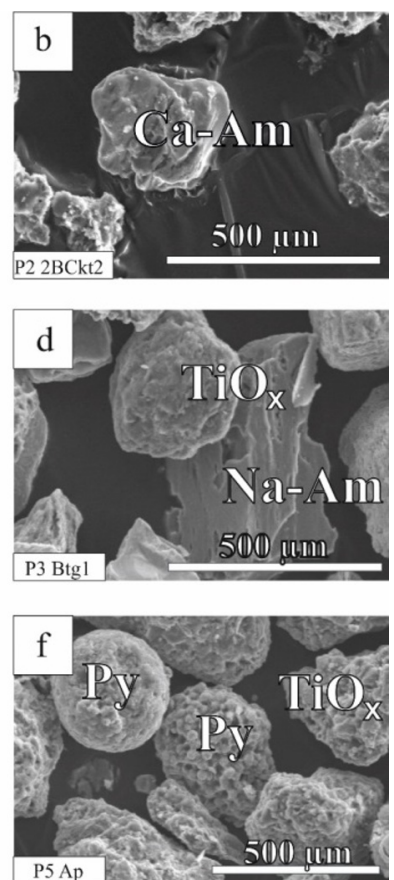
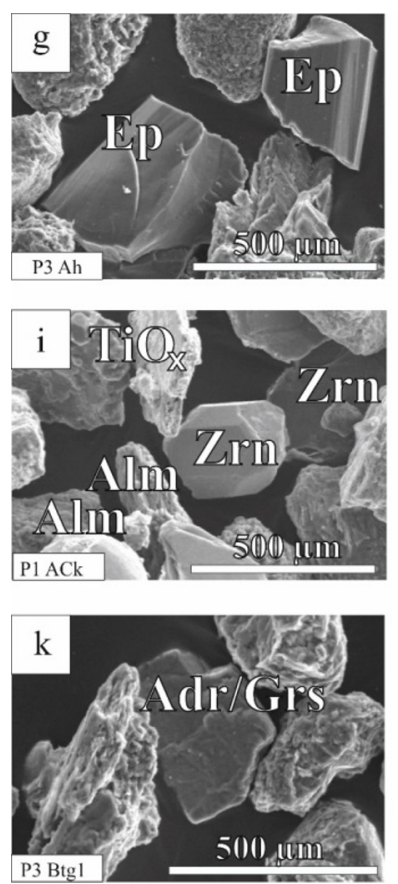
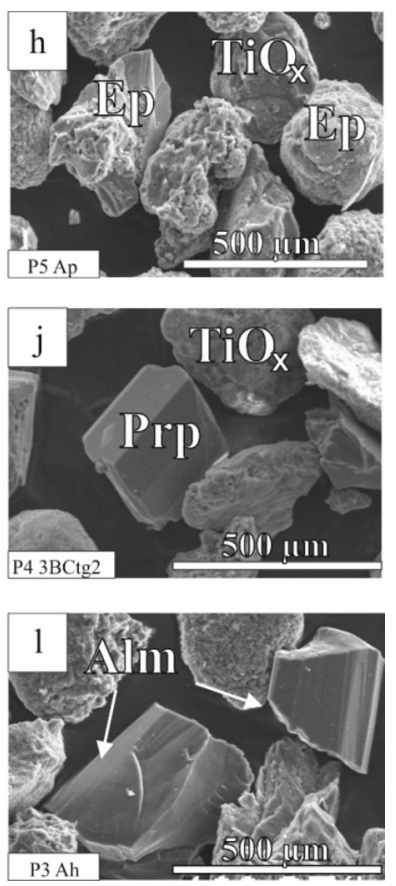

Figure 5 Scanning Electron Microscopy analysis: a) Ca-Am - Ca-amphiboles, TiOx - titanium oxide; b) Ca-Am - Caamphiboles; c) Ortho-Am - Ortho-amphiboles; d) Na-Am - Na-amphiboles, TiOx - titanium oxide; e) Py - Pyrite framboid; f) Py - Pyrite framboid, TiOx - titanium oxide; g) Ep - Epidote; h) Ep - Epidote, TiOx - titanium oxide; i) Zrn - Zircon, TiOx - titanium oxide, Alm - Almandine; j) Prp - Pyrope, TiOx - titanium oxide; k) Adr/GrsAndradite/ Grossular; l) Alm -Almandine.

horizons) - was noted, suggesting an alkaline igneous origin (Figure 4; Table 6).

\subsection{Micromorphological features}

The studied soils were mostly characterized by subangular blocky (Figure 6c, e, g) and vughy microstructures (e.g. Figure 6g, Table 7A) with planar (e.g. Figure 6c, e, g; Figure 7a; Figure 8a, c) and vughs (Figure 6g; Figure 7e, g) types of voids, typical for such microstructures. Within the A horizons of some of the soils (e.g. P1, P4, P6) crumby types of microstructure were seen (Figure 6a), together with channel types of voids and partially compound packing voids (Figure 7e). The related destitution pattern was characterized as porphyric with various coarse and fine ratios (c:f ratio) (Figure 6a, f; Figure 7c, g; Figure 8c, g).

Various b-fabric patterns were recognized in studied soils. Surface horizons of P1 (Ahk1, Ahk2), $\mathrm{P} 2$ (Ah1, Ah2), $\mathrm{P} 4$ (Ap, ABt) and partially AB, Btg1 and 2Btg2 horizons of P6 represented undifferentiated types of b-fabric (Figure 8f). The horizons $\mathrm{ACk}$ and $2 \mathrm{Ck} 1$ of $\mathrm{P} 1$ and partially $2 \mathrm{BCk}$ and 2 BCkt1 showed crystallitic types of b-fabric (Figure 6d). However, mostly speckled (Figure 6h;
Figure $7 \mathrm{~d}, \mathrm{~h}$; Figure $8 \mathrm{~b}, \mathrm{~d}, \mathrm{f}, \mathrm{h})$, porostraited (Figure 6h; Figure 7d; Figure 8d, h) and granostriated (Figure $7 \mathrm{~h}$ ) types of b-fabric were recognized.

Among the pedofeatures, the secondary calcium carbonates were seen in P1 in the form of typic nodules (Figure 6d), carbonate coatings (Figure 6d) and in P2 showing the secondary calcium carbonate accumulations (Figure 6h). Almost every horizon was characterized by the presence of iron-manganese impregnations (Figure 6f; Figure 7a, c, g; Figure 8a, c, e) and, rarely, nodules. Within the soils $\mathrm{P}_{2}, \mathrm{P}_{3}, \mathrm{P}_{4}, \mathrm{P}_{5}$ and $\mathrm{P} 6$, the illuvial character of pedofeatures was recognized, mostly in form of infillings of illuvial clay (Figure 7b, h; Figure 8f, h), typic clay coatings (Figure 8b, d) and crescent clay coatings (Figure $7 \mathrm{~b}$ ).

Organic matter occurred in various forms, however mostly organ and tissue residues (Table $7 \mathrm{~B}$, Figure $6 \mathrm{e}, \mathrm{g}$ ) as well as the amorphous fine organic matter were seen.

Among the rock fragments, limestone, limestone with calcite veins, sandstone and shale were seen. The mineralogical composition of soil included calcite (soil P1, P2 and P6) in the whole solum. The soils $\mathrm{P}_{3}, \mathrm{P}_{4}$ and $\mathrm{P}_{5}$ contained calcite only in the lower horizon. Almost every soil was 

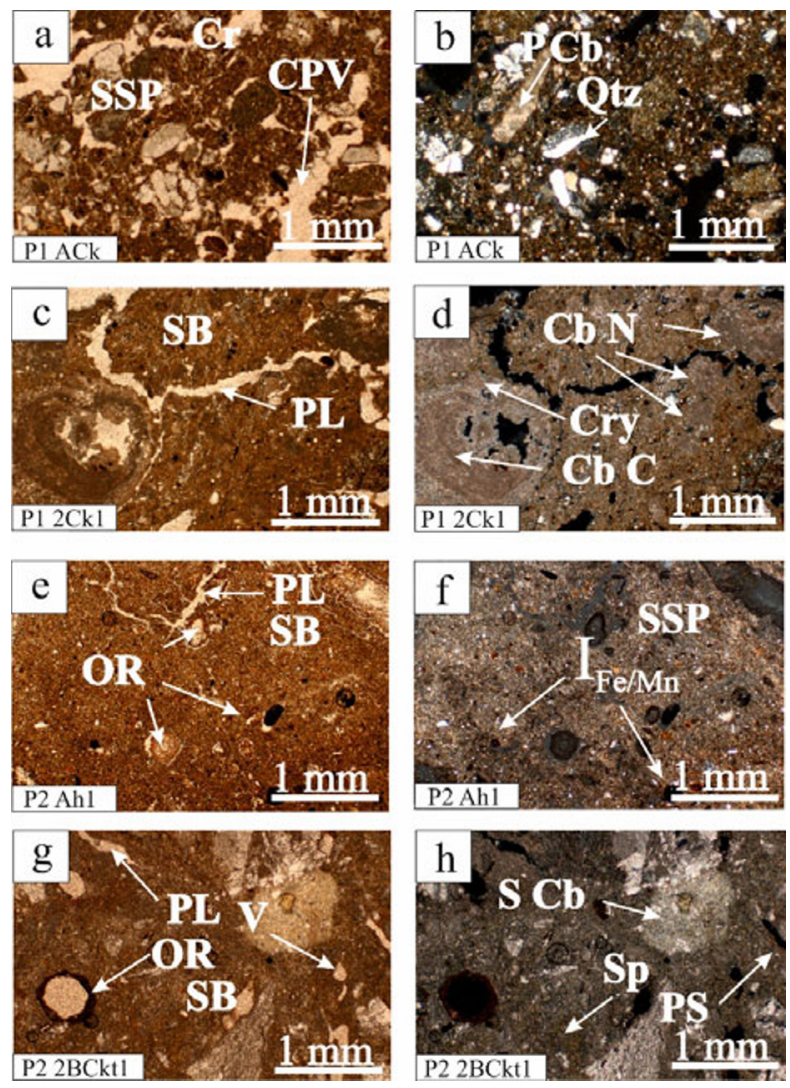

Figure 6 Microphotographs of thin rock sections from $\mathrm{P}_{1}$ and P2. Explanations: (a, b): $(\mathrm{Cr})$ - crumb type of microstructure, (SSP) - single-spaced porphyric type of related distribution, (CPV) - compound packing voids, (Qtz) - quartz, (PCb) - primary calcium carbonate; (c, d): (SB) - subangular blocky type of microstructure, (PL) planar type of voids, $(\mathrm{Cb} \mathrm{N})$ - carbonate typic nodules, $(\mathrm{Cb}$ C) - carbonate coatings, (Cry) - crystallitic b-fabric; (e, f): (SB) - subangular blocky type of microstructure, (PL) planar type of voids, (OR) - organ residues, (SSP) - singlespaced porphyric type of related distribution; ( $\left.\mathrm{I}_{\mathrm{Fe} / \mathrm{Mn}}\right)$ iron/manganese impregnations; (g, h): (OR) - organ residues, (SB) - subangular blocky type of microstructure, (PL) - planar type of voids, (V) - vughs type of voids, (Sp) - speckled b-fabric, (PS) - porostriated b-fabric, (S Cb) accumulation of secondary carbonates. Bar length $=1 \mathrm{~mm}$. a, c, e, g - PPL microphotographs, b, d, f, h - XPL microphotographs.

characterized by the occurrence of well-visible quartz (e.g. Figure 6b; Figure 7f). Moreover, in soils $\mathrm{P}_{1}$ and $\mathrm{P}_{5}$, plagioclase was seen, whereas in soil $P_{5}$ clay minerals were noted.

\section{Discussion}

The sampled calcium carbonate-rich soils from the area of Polish Carpathians were mostly
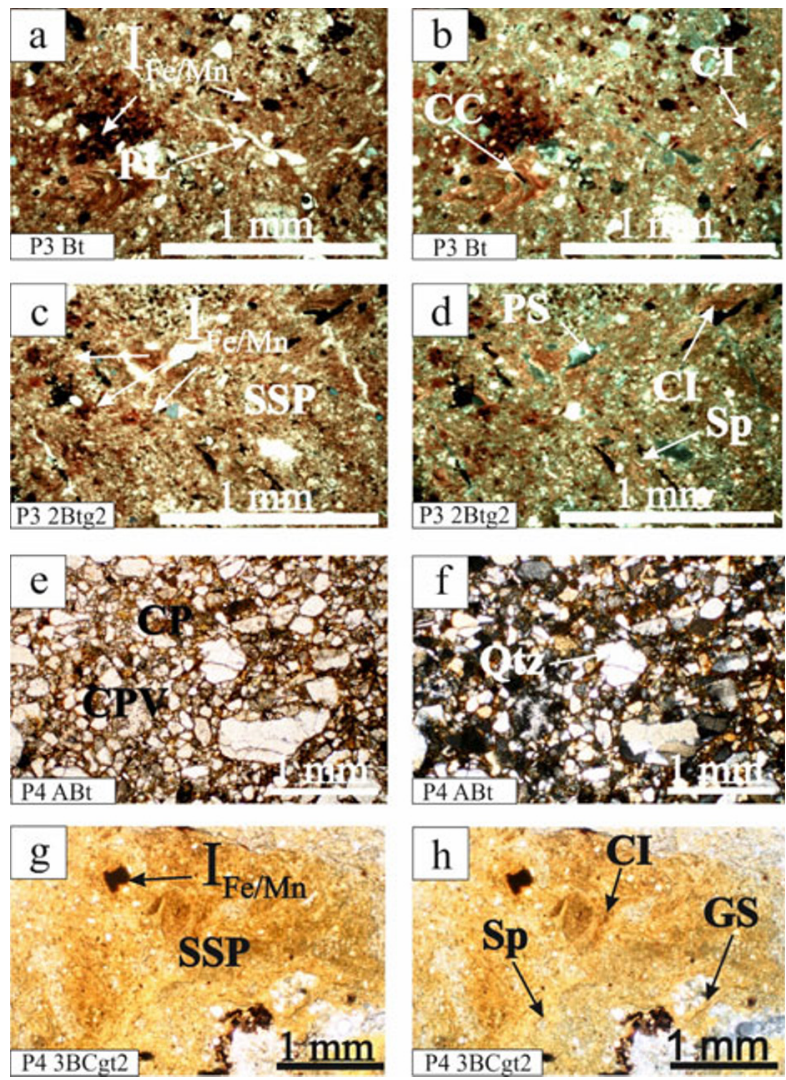

Figure 7 Microphotographs of thin rock sections from $\mathrm{P}_{3}$ and $\mathrm{P}_{4}$. Explanations: $(\mathrm{a}, \mathrm{b}):\left(\mathrm{I}_{\mathrm{Fe} / \mathrm{Mn}}\right)-$ iron/manganese impregnations, (PL) - planar type of voids, (CC) - crescent clay coatings, (CI) - infillings of illuvial clay; (c, d): ( $\left.\mathrm{IFe}_{\mathrm{Mn}}\right)$ - iron/manganese impregnations, (SSP) - single-spaced porphyric type of related distribution, $(\mathrm{CI})$ - infillings of illuvial clay, $(\mathrm{Sp})$ - speckled b-fabric, (PS) - porostriated b-fabric; (e, f): (CPV) - compound packing voids, (CP) - close porphyric, Qtz) - quartz, (g, h): (SSP) - single-spaced porphyric type of related distribution, ( $\mathrm{I}_{\mathrm{Fe} / \mathrm{Mn})}$ iron/manganese impregnations, (Sp) - speckled bfabric, (GS) - granostriated b-fabric, (CI) - infillings of illuvial clay. Bar length $=1 \mathrm{~mm}$. a, c, e, g - PPL microphotographs; b, d, f, h - XPL microphotographs.

heterogeneous and represented lithic discontinuities (Tables 8A and 8B). Different criteria and tools such as i) morphological (grainsize distribution and coarse fragments), ii) geochemical (content and distribution of major oxides as well as $\mathrm{Hf}$ and $\mathrm{Zr}$ content), iii) mineralogical (heavy mineral composition and distribution) (Martignier et al. 2015; Schaetzl and Anderson 2005; Schaetzl 2008; Muhs 2018; Waroszewski et al. 2015, 2018a, 2018b) as well as iv) micromorphological (c:f ratio, type of micromass and occurrence and distribution of pedofeatures) (Stoops et al. 2010) were applied in 


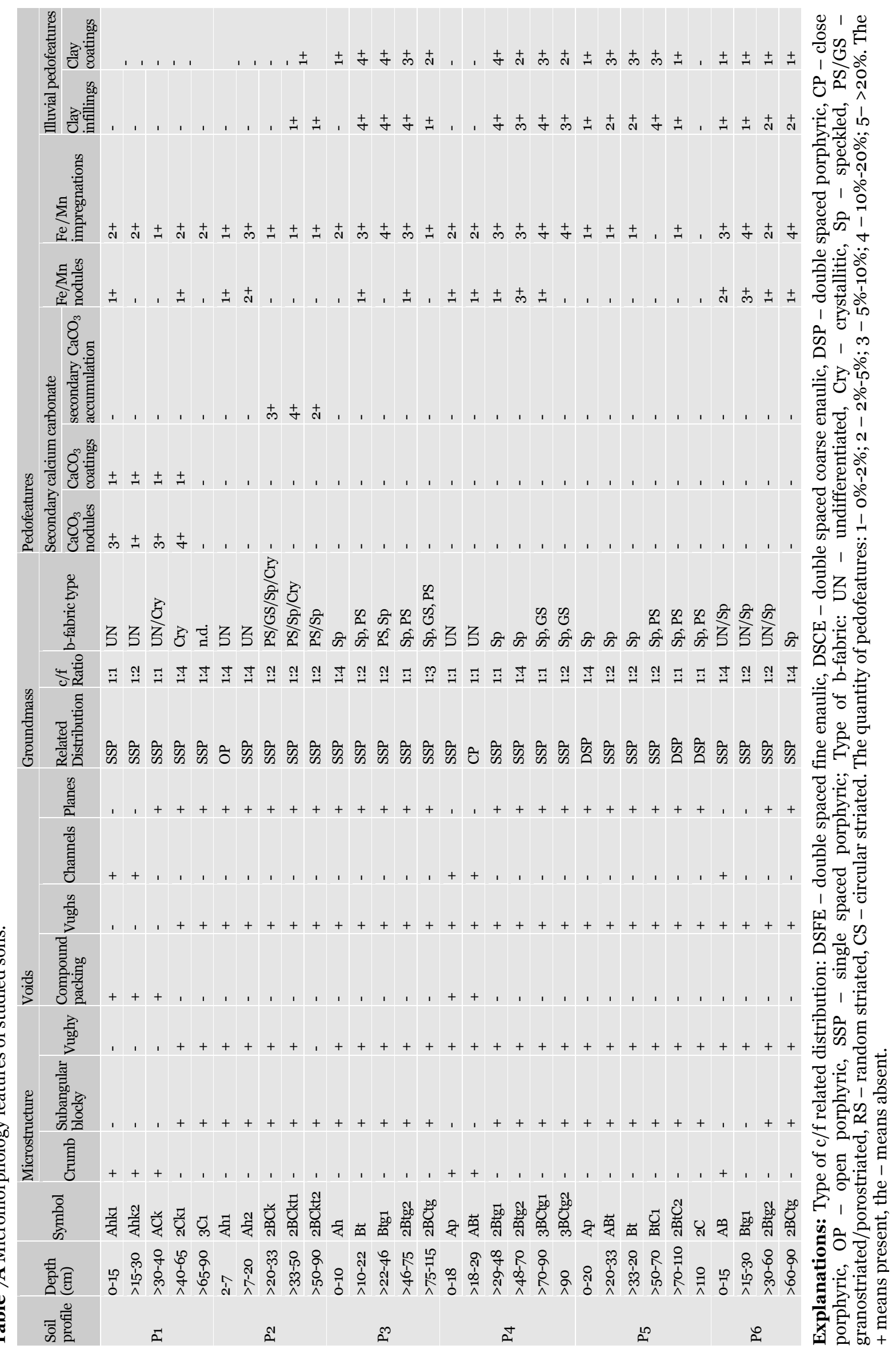


Table 7 B Micromorphology features of studied soils.

\begin{tabular}{|c|c|c|c|c|c|c|c|c|c|c|c|c|c|}
\hline \multirow[b]{2}{*}{$\begin{array}{l}\text { Profile } \\
\text { number }\end{array}$} & \multirow[b]{2}{*}{$\begin{array}{l}\text { Depth } \\
(\mathrm{cm})\end{array}$} & \multirow[b]{2}{*}{ Symbol } & \multicolumn{3}{|c|}{ Organic matter } & \multicolumn{4}{|c|}{ Mineral Grains composition } & \multicolumn{4}{|c|}{ Rock fragments } \\
\hline & & & $\begin{array}{l}\text { Organ } \\
\text { residues }\end{array}$ & $\begin{array}{l}\text { Tissue } \\
\text { residues }\end{array}$ & $\begin{array}{l}\text { Organic } \\
\text { fine } \\
\text { material }\end{array}$ & $\begin{array}{l}\text { Primary } \\
\text { calcium } \\
\text { carbonate }\end{array}$ & Quartz & Plagioclase & $\begin{array}{l}\text { Clay } \\
\text { minerals }\end{array}$ & Limestone & $\begin{array}{l}\text { Limestone } \\
\text { with calcite } \\
\text { veins }\end{array}$ & Sandstone & Shale \\
\hline \multirow{5}{*}{ P1 } & $0-15$ & Ahk1 & + & + & + & + & + & + & - & + & + & + & - \\
\hline & $>15-30$ & Ahk2 & + & + & + & + & + & + & - & + & + & - & - \\
\hline & $>30-40$ & $\mathrm{ACk}$ & + & + & + & + & + & + & - & + & - & + & - \\
\hline & $>40-65$ & 2Ck1 & - & - & - & + & + & + & - & + & + & - & - \\
\hline & $>65-90$ & $3 \mathrm{C} 1$ & - & - & - & + & + & + & - & + & - & - & - \\
\hline \multirow{5}{*}{ P2 } & $2-7$ & Ah1 & + & + & - & + & - & - & + & - & - & + & + \\
\hline & $>7-20$ & Ah2 & + & + & - & + & - & - & - & - & - & - & + \\
\hline & $>20-33$ & 2BCk & + & - & - & + & - & - & - & - & - & - & - \\
\hline & $>33-50$ & 2BCkt1 & + & - & - & + & - & - & - & - & - & - & - \\
\hline & $>50-90$ & 2BCkt2 & + & - & - & + & - & - & - & - & - & - & - \\
\hline \multirow{5}{*}{$\mathrm{P}_{3}$} & $0-10$ & Ah & + & + & + & - & + & - & - & - & - & + & - \\
\hline & $>10-22$ & $\mathrm{Bt}$ & - & + & + & - & + & - & - & - & - & - & - \\
\hline & $>22-46$ & Btg1 & - & - & + & - & + & - & - & - & - & - & - \\
\hline & $>46-75$ & 2Btg2 & - & - & + & - & + & - & - & - & - & - & - \\
\hline & $>75^{-115}$ & 2BCtg & - & + & + & + & + & - & - & - & - & + & - \\
\hline \multirow{6}{*}{$\mathrm{P}_{4}$} & o-18 & Ap & + & - & - & - & + & - & - & - & - & + & - \\
\hline & $>18-29$ & $\mathrm{ABw}$ & - & + & - & - & + & - & - & - & - & + & + \\
\hline & $>29-48$ & 2Btg1 & + & + & - & - & + & - & - & - & - & + & + \\
\hline & $>48-70$ & 2Btg2 & + & + & - & - & + & - & - & - & - & + & - \\
\hline & $>70-90$ & $3^{\mathrm{BCtg} 1}$ & + & + & - & - & + & - & - & - & - & + & - \\
\hline & $>90$ & 3BCtg2 & - & - & + & + & + & - & - & - & - & + & - \\
\hline \multirow{6}{*}{$\mathrm{P}_{5}$} & $0-20$ & Ap & + & + & - & - & + & - & + & - & - & - & + \\
\hline & $>20-33$ & $\mathrm{ABt}$ & + & + & - & - & + & - & + & - & - & - & + \\
\hline & $>33-50$ & $\mathrm{Bt}$ & - & - & - & - & + & - & + & - & - & - & + \\
\hline & $>50-70$ & BtC1 & - & - & - & - & + & - & + & - & - & - & + \\
\hline & $>70-110$ & 2BtC2 & - & - & - & - & + & - & + & - & - & - & + \\
\hline & $>110$ & $2 \mathrm{C}$ & - & - & - & - & + & - & + & - & - & - & + \\
\hline \multirow{4}{*}{ P6 } & o-15 & $\mathrm{AB}$ & + & + & - & - & + & - & - & - & - & + & + \\
\hline & $>15-30$ & Btg1 & + & - & - & - & + & - & - & - & - & + & + \\
\hline & $>30-60$ & 2Btg2 & - & + & - & + & + & - & - & - & - & + & + \\
\hline & $>60-90$ & 2BCtg & - & - & - & + & + & - & - & - & - & + & + \\
\hline
\end{tabular}

Explanations: The + means present, the - means absent.

this study to detect lithic discontinuities.

\subsection{Grain size distribution}

The occurrence of lithic discontinuities based on changes in grain size distribution (Table 8A) has been repeatedly described in the literature (e.g. Ande et al. 2010; Arnold 1968; Kacprzak and Salamon 2013; Lorz et al. 2010; and Waroszewski et al. 2013, 2015), and these were detected in every studied soil. In soil P1, large textural diversity was detected, however the most visible in horizon $3 \mathrm{C} 1$ (see Results section). Horizon $3 \mathrm{C} 1$ represented almost a two-fold enrichment with the silt fraction (up to 53\%, Appendix 2). Considering the evident textural differences (Figure 3), it seems to be very likely this horizon consisted of the admixture of allochthonous material of an aeolian origin. It also manifested by the high Uniformity Values and Lithological Discontinuity Index values $\left(\mathrm{UV}_{1}\right.$ and $\mathrm{UV}_{2}$ and $\mathrm{LD}_{2}$; Appendix 1; Table 8A; Table 9). In addition, profile P1 exhibited a lithic discontinuity, based on the $\mathrm{UV}_{1}$ values between Ahk1 and Ahk2, mostly due to a noticeable change of every subfraction of sand content (Appendix 2; Table 9).

Similar pattern to soil P1 was noted in profile $\mathrm{P}$ 3. A lithic discontinuity was identified within the solum between the Btg1 and 2Btg2 horizons (Table $8 \mathrm{~A})$. In terms of the $\mathrm{LDI}_{2}$ index, based on the differences in the content of sand subfraction (IUSS Working Group 2015; Kowalska et al. 2016; Appendix 1), more than a sevenfold difference in the indicator's values between Btg1 and 2Btg2 was noted (Table 9). When considering the $\mathrm{P}_{3}$ grain size distribution, the content of silt and the fine sand was the highest in the middle and lower horizons: Btg, $2 \mathrm{Btg} 2$ and $2 \mathrm{Cg}$. Two main causes should be contemplated for such distinctness within $\mathrm{P}_{1}$ and $\mathrm{P}_{3}$ in terms of grain size distribution. First, this may be a result of the gravity-driven transportation of material from upper parts of the slope and covered by the newly deposited soil material (Kacprzak et al. 2010). Second, it may result from the geological layering of various 
Table 8A Summarized data regarding indices of lithic discontinuity in the studied soils.

\begin{tabular}{|c|c|c|c|c|c|c|c|c|c|}
\hline \multicolumn{2}{|l|}{ Profile } & \multicolumn{2}{|c|}{ P1 } & \multirow{2}{*}{$\begin{array}{l}\text { P2 } \\
\text { / Ah2/ } \\
\text { 2BCk }\end{array}$} & \multirow{2}{*}{$\begin{array}{l}\mathrm{P} 3 \\
\mathrm{Btg} / \\
\text { 2Btg2 }\end{array}$} & \multicolumn{2}{|c|}{$\mathrm{P}_{4}$} & \multirow{2}{*}{$\begin{array}{l}\mathrm{P} 5 \\
\text { / } \mathrm{BtC1} / \\
2 \mathrm{BtC} 2\end{array}$} & \multirow{2}{*}{$\begin{array}{l}\text { P6 } \\
\text { Btg1/ } \\
2 \text { Btg2 }\end{array}$} \\
\hline Lithic discor & ntinuity occurrence (horizons directly superimposed) & $\begin{array}{l}\text { ACk/ } \\
\text { 2Ck1 }\end{array}$ & $\begin{array}{l}2 \mathrm{Ck} 1 / \\
3 \mathrm{C} 1\end{array}$ & & & $\begin{array}{l}\mathrm{ABt} / \\
2 \mathrm{Bg} 1\end{array}$ & $\begin{array}{l}\text { 2Btge/ } \\
\text { 3BCtg1 }\end{array}$ & & \\
\hline \multirow{9}{*}{$\begin{array}{l}\text { Lithic } \\
\text { discontinuity } \\
\text { indices } \\
\text { according to } \\
\text { WRB 2015 } \\
\text { (IUSS, } \\
\text { Working } \\
\text { Group } \\
\text { 2015)* }\end{array}$} & $\begin{array}{l}\text { An abrupt difference in particle-size distribution that is } \\
\text { not solely associatedwith a change in clay content } \\
\text { resulting from pedogenesis }\end{array}$ & - & Sor & - & - & - & 250 & - & - \\
\hline & $\begin{array}{l}\text { A difference of } \geq 25 \% \text { in the ratio coarse sand to medium } \\
\text { sand, and a difference of } \geq 5 \% \text { (absolute) in the content of } \\
\text { coarse sand and/or medium sand; }\end{array}$ & - & - & + & - & + & + & - & + \\
\hline & $\begin{array}{l}\text { A difference of } \geq 25 \% \text { in the ratio coarse sand to fine sand, } \\
\text { and a difference of } \geq 5 \% \text { (absolute) in the content of coarse } \\
\text { sand and/or fine sand }\end{array}$ & + & + & + & + & + & + & + & + \\
\hline & $\begin{array}{l}\text { A difference of } \geq 25 \% \text { in the ratio medium sand to fine } \\
\text { sand, and a difference of } \geq 5 \% \text { (absolute) in the content of } \\
\text { medium sand and/or fine sand }\end{array}$ & + & + & + & + & - & - & - & - \\
\hline & $\begin{array}{l}\text { Rock fragments that do not have the same lithology as the } \\
\text { underlying continuous rock; }\end{array}$ & + & + & - & - & - & - & - & - \\
\hline & $\begin{array}{l}\text { A layer containing rock fragments without weathering } \\
\text { rinds overlying a layer containing rocks with weathering } \\
\text { rinds }\end{array}$ & + & + & + & - & - & - & - & - \\
\hline & $\begin{array}{l}\text { A layer with angular rock fragments overlying or } \\
\text { underlying a layer with rounded rock fragments }\end{array}$ & - & + & - & - & - & - & - & - \\
\hline & $\begin{array}{l}\text { A layer with a larger content of coarse fragments overlying } \\
\text { a layer with a smaller content of coarse fragments }\end{array}$ & - & + & + & + & - & - & - & + \\
\hline & $\begin{array}{l}\text { Abrupt differences in colour not resulting from } \\
\text { pedogenesis }\end{array}$ & - & - & + & - & - & - & - & - \\
\hline
\end{tabular}

Explanations: *the following indices have been not taken into account during this study: marked differences in size and shape of resistant minerals between superimposed layers as shown by micromorphological or mineralogical methods; differences in the $\mathrm{TiO}_{2} / \mathrm{ZrO}_{2}$ ratios of the sand fraction by a factor of 2 . The + means present, the - means absent.

Table 8B Summarized data regarding indices of lithic discontinuity in studied soils.

Profile
Lithic discontinuity occurrence (horizons directly
superimposed)
$\mathrm{UV}_{1}$ (Cremeens and Mokma 1986)
$\mathrm{UV}_{2}$ (Kowalska et al. 2016)
$\mathrm{UV}_{1}$ (IUSS, Working Group 2015)
$\mathrm{UV}_{2}$ (IUSS, Working Group 2015)
Geochemistry values
Heavy minerals
Micromorphology
abrupt differences in colour not resulting from pedogenesis
Explanations: The + means present, the - means absent.

\begin{tabular}{|c|c|c|c|c|c|c|c|}
\hline \multicolumn{2}{|l|}{$\mathrm{P}_{1}$} & \multirow{3}{*}{$\begin{array}{l}\mathrm{P} 2 \\
\text { Ah2/ } \\
\text { 2BCk }\end{array}$} & \multirow{3}{*}{$\begin{array}{l}\mathrm{P} 3 \\
\mathrm{Btg} / \\
2 \mathrm{Btg} 2\end{array}$} & \multicolumn{2}{|l|}{$\mathrm{P}_{4}$} & \multirow{3}{*}{$\begin{array}{l}\mathrm{P} 5 \\
\mathrm{BtC} 1 / \\
2 \mathrm{BtC} 2\end{array}$} & \multirow{3}{*}{$\begin{array}{l}\text { P6 } \\
\text { Btg1/ } \\
\text { 2Btg2 }\end{array}$} \\
\hline $\mathrm{ACk} /$ & 2Ck1/ & & & $\mathrm{ABt} /$ & 2Btg2/ & & \\
\hline 2Ck1 & $3 \mathrm{C}_{1}$ & & & 2Bg1 & $3^{B C t g} 1$ & & \\
\hline - & - & - & - & - & - & - & - \\
\hline - & - & + & - & + & + & - & + \\
\hline+ & + & + & + & + & + & + & + \\
\hline+ & + & + & + & - & - & - & - \\
\hline+ & + & - & - & - & - & - & - \\
\hline+ & + & + & - & - & - & - & - \\
\hline - & + & - & - & - & - & - & - \\
\hline - & - & + & - & - & - & - & - \\
\hline
\end{tabular}

weathered materials consisting of, e.g. various mixed sandstone and limestone or shale (Kacprzak and Salamon 2013), and indicates a variable environment of sedimentary rocks.

Differences in grain size distribution between $\mathrm{ABt}$ and $2 \mathrm{Btg} 1$, and $2 \mathrm{Btg} 2$ and ${ }_{3} \mathrm{BCtg} 1$ of $\mathrm{P} 4$ were evident when considering the changes in the sand and clay fraction. In the upper part - the Ap and ABt horizons - loose sand probably originated from physical destruction of sandstone, which created the sand-rich (silty-sand) cover (Figure 3; Ande and Sejobi 2010; Philips 2004). It is very likely that the occurrence of sandy (silty-sand) sediments was accompanied by the translocation and mixing processes of the soil material as in the profiles $\mathrm{P}_{1}$ and $\mathrm{P}_{3}$ (Semmel and Terhorst 2010; Wicik 1986). As visible in the thin sections (Figure 7h), translocation of clay particles in horizons 2Btg1, 2Btg2, 3BCtg1 and 3 BCtg2 was present within $\mathrm{P}_{4}$ (Appendix 2), suggesting that lessivage processes influenced the texture variability.

Moreover, the high content of the silt fraction in the whole of profile $\mathrm{P} 4$ - from 41 to $61 \%$ (with an especially high fine silt fraction) - should be highlighted (Appendix 2; Figure 3). The processes acting in the formation of the colluvial deposits did 
Table 9 Lithic discontinuity values (UV1, UV2, LDI1, LDI2) in studied soils.

\begin{tabular}{|c|c|c|c|c|c|c|}
\hline $\begin{array}{l}\text { Soil } \\
\text { profile }\end{array}$ & $\begin{array}{l}\text { Depth } \\
\text { (cm) }\end{array}$ & $\begin{array}{l}\text { Soil } \\
\text { horizon }\end{array}$ & $\mathrm{UV}_{1}$ & $\mathrm{UV}_{2}$ & $\mathrm{LDI}_{1}$ & $\mathrm{LDI}_{2}$ \\
\hline \multirow{6}{*}{$\mathrm{P} 1$} & $0-15$ & Ahk1 & 0.86 & 0.88 & -0.30 & 0.86 \\
\hline & $>15-30$ & Ahk2 & -0.13 & -0.67 & -0.09 & 0.31 \\
\hline & $>30-40$ & $\mathrm{ACk}$ & 0.09 & 0.33 & -0.24 & 1.39 \\
\hline & $>40-65$ & 2Ck1 & -0.62 & -0.56 & 0.53 & 1.20 \\
\hline & $>65-90$ & $3 \mathrm{C} 1$ & 1.47 & 1.09 & 0.09 & 0.64 \\
\hline & $>90-120$ & $3 \mathrm{C} 2$ & - & - & - & - \\
\hline \multirow{5}{*}{ P2 } & $0-7$ & Ah1 & 2.52 & -0.50 & 0.00 & 0.00 \\
\hline & $>7-20$ & Ah2 & 2.87 & 3.20 & -0.20 & 0.78 \\
\hline & $>20-33$ & 2BCk & -0.13 & -0.16 & 0.25 & 0.80 \\
\hline & $>33-50$ & 2BCkt1 & -0.15 & 0.00 & -0.20 & 1.56 \\
\hline & $>50-90$ & 2BCkt2 & - & - & - & - \\
\hline \multirow{5}{*}{$\mathrm{P}_{3}$} & $0-10$ & Ah & -0.52 & -0.37 & -0.33 & 10.71 \\
\hline & $>10-22$ & $\mathrm{Bt}$ & 0.11 & -0.37 & 0.00 & 7.20 \\
\hline & $>22-46$ & Btg1 & 0.00 & -0.08 & 1.00 & 1.50 \\
\hline & $>46-75$ & 2Btg2 & -0.02 & 0.54 & -0.25 & 0.59 \\
\hline & $>75-115$ & 2BCtg & - & - & - & - \\
\hline \multirow{6}{*}{$\mathrm{P}_{4}$} & $0-18$ & Ap & 0.06 & -0.59 & -0.20 & 0.94 \\
\hline & $>18-29$ & $\mathrm{ABt}$ & -0.05 & -0.17 & 0.50 & 3.70 \\
\hline & $>29-48$ & 2Btg1 & -0.58 & -0.42 & -0.33 & 5.40 \\
\hline & $>48-70$ & 2Btg2 & 1.04 & -0.09 & 0.00 & 0.33 \\
\hline & $>70-90$ & 3BCtg1 & -0.11 & -0.30 & -0.50 & 4.00 \\
\hline & $>90$ & 3BCtg2 & - & - & - & - \\
\hline \multirow{6}{*}{$\mathrm{P}_{5}$} & $0-20$ & Ap & -0.14 & 0.00 & 1.00 & 2.00 \\
\hline & $>20-33$ & $\mathrm{ABt}$ & 0.07 & 0.48 & 0.00 & 4.50 \\
\hline & $>33-50$ & $\mathrm{Bt}$ & -0.21 & -0.22 & 0.00 & 1.33 \\
\hline & $>50-70$ & BtC1 & 0.05 & -0.60 & 0.00 & 2.00 \\
\hline & $>70-110$ & 2BtC2 & 0.00 & -0.27 & 0.00 & 0.00 \\
\hline & $>110$ & $2 \mathrm{C}$ & - & - & - & - \\
\hline \multirow{4}{*}{ P6 } & $0-15$ & $\mathrm{AB}$ & 0.25 & -0.82 & 0.00 & 1.00 \\
\hline & $>15-30$ & Btg1 & 1.25 & 1.37 & -0.50 & 4.00 \\
\hline & $>30-60$ & 2Btg2 & -0.41 & 0.65 & 1.00 & 2.00 \\
\hline & $>60-90$ & 2BCtg & - & - & - & - \\
\hline
\end{tabular}

Explanations: values in bold indicate presence of lithological discontinuities, according to studies given by Cremeens and Mokma (1986), IUSS Working Group (2015), Kowalska et al. (2016), and Schaetzl and Anderson (2005) (Appendix 1 ).

not modify the grain size distribution; slight changes only occurred in sand and clay contents. On its face, it seems that the addition of allochthonous silt had a great effect on the entire solum. During the transport along the slope, aeolian silt could be partially eroded and mixed into the soils, even in the deeper horizons (Waroszewski et al. 2013).

Admixture of aeolian silt should be under consideration in P2 and P6 as well. Enrichment (up to 57\%; Appendix 2) in the silt fraction was evident in the uppermost part of $\mathrm{P}_{2}$, in the Ah1 and Ah2 horizons (Appendix 2; Figure 3). The observed arrangement corresponds with the assumptions of Kacprzak and Derkowki (2007), who noted that the factor responsible for the silty character of surface horizons is a possible admixture of aeolian material, which could be connected with loess deposits located at the foot of the Pieniny Mts. Furthermore, $\mathrm{UV}_{2}$ (P2) and $\mathrm{LDI}_{2}$ (P6) (Cremeens and Mokma 1986; IUSS Working Group 2015; Kowalska et al. 2016) definitively showed a discontinuity, with the LDI2 values in P2 particular nearly reaching 3 and the LDI values reaching 4 in P6 (Table 9), unambiguously showing the different foreign provenance of the surface horizons (Table 9).

According to the $\mathrm{UV}_{2}$ values, the lithic discontinuity appeared to occur between $\mathrm{AB}$ and Btg1 horizons of soil P6, caused by a sudden increase of clay fraction and decrease of sand fraction below the lithic discontinuity. Furthermore, $\mathrm{UV}_{2}$ allowed recognition of the discontinuities between $2 \mathrm{Btg} 2$ and $2 \mathrm{BCtg}$, where the sand fraction increased at the expense of silt content (Appendix 2). The enrichment in the silt fraction of P6, especially in the surface $\mathrm{AB}$ and Btg1 horizons seems to be due to aeolian influence from a local source, not a loess-related pattern (Waroszewski et al. 2018a).

Examining soil $\mathrm{P}_{5}$, in terms of size-grain distribution, the differences in composition indicating the lithic discontinuity were not so obvious. Although profile $\mathrm{P}_{5}$ seemed to be rather homogenous at first sight, the lithic discontinuity was, however, shown by $\mathrm{UV}_{1}, \mathrm{UV}_{2}$ and LDI (Table 4). Within $P_{5}$, the silt fraction prevailed (especially fine silt, Appendix 2). In silt-textured materials of $\mathrm{P}_{5}$ superimposed on sandstone and shale colluvium, well-developed illuvial clay features were noted (Figure 8b, d). Even though in this soil the clay illuviation had a rather weak and shortrange character, it did not cause the formation of an argic horizon and thus did not allow classification of this soil as Luvisol. It is also likely that the illuvial horizon was blurred through past erosion processes and has now been replaced with the cambic horizon; this resulted in the classification of this soil as a Cambisol (Kowalska et al. 2019; Waroszewski et al. 2018a).

\subsection{Coarse fragments}

The arrangement of coarse fragments in P2 and P6 should be under consideration as evidence for the occurrence of an aeolian silt admixture. The 

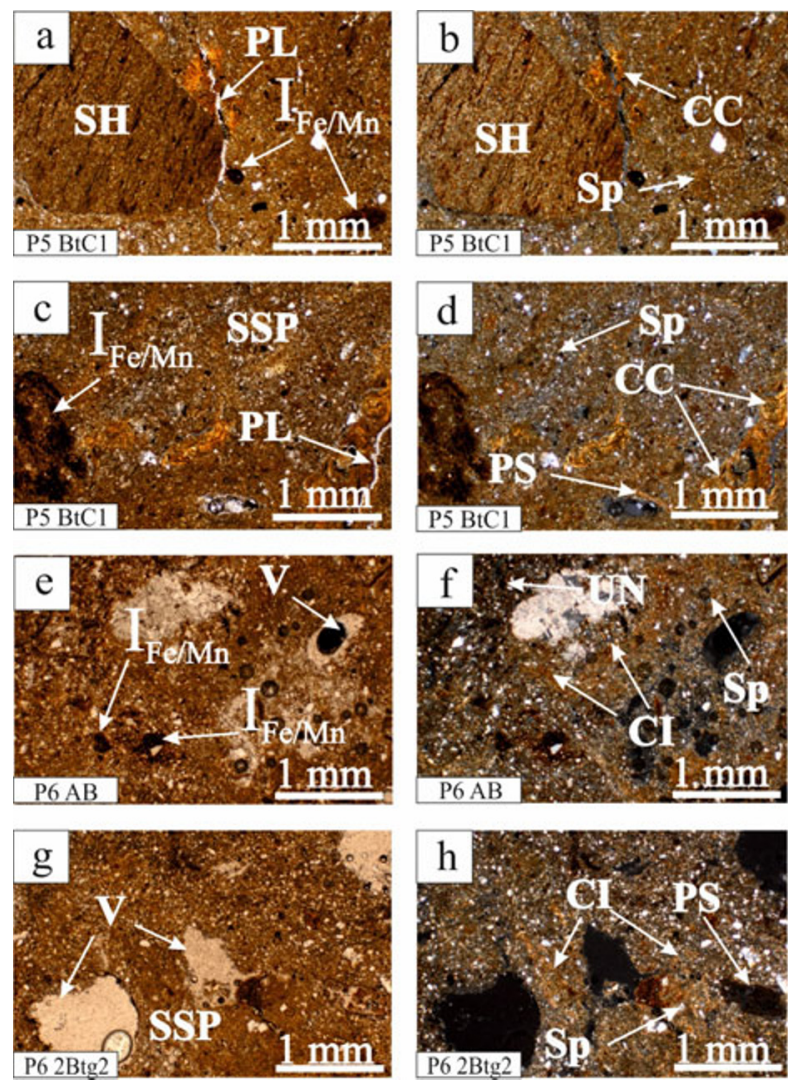

Figure 8 Microphotographs of thin rock sections from P5 and P6. Explanations: $(\mathrm{a}, \mathrm{b})$ : $(\mathrm{SH})$ - fragments of shale, (PL) - planar type of voids, $\left(\mathrm{I}_{\mathrm{Fe} / \mathrm{Mn})}\right.$ iron/manganese impregnations, (Sp) - speckled bfabric, (CC) - typic clay coatings; (c, d): $\left(\mathrm{I}_{\mathrm{Fe} / \mathrm{Mn}}\right)$ iron/manganese impregnations, (SSP) - single-spaced porphyric type of related distribution, (PL) - planar type of voids, (CC) - typic clay coatings, (Sp) - speckled b-fabric, (PS) - porostriated b-fabric; (e, f): (V) - vughs type of voids, $\left(\mathrm{I}_{\mathrm{Fe} / \mathrm{Mn}}\right)$ - iron/manganese impregnations, (CI) - infillings of illuvial clay, (UN) - undifferentiated b-fabric, (Sp) - speckled b-fabric; $(\mathrm{g}, \mathrm{h})$ : (V) - vughs type of voids, (SSP) - single-spaced porphyric type of related distribution, (CI) - infillings of illuvial clay, (Sp) - speckled b-fabric, (PS) - porostriated b-fabric. Bar length = 1mm. a, c, e, g - PPL microphotographs; b, d, f, $\mathrm{h}-$ XPL microphotographs.

surface horizons (Ah1 and Ah2 for P2 and $\mathrm{AB}$ and Btg1 for P6) contained a significantly lower content of coarse fragments, and its fraction was mainly fine silt (Table 3; Appendix 2). Moreover, coarse fragments distinctly accumulated at the boundary of lithic discontinuities, showing the foreign origin of the overlying soil material. Similar results concerning coarse fragments have also been found by Waroszewski et al. (2013), who described discontinuities among the uppermost sandy (or a sandy-silty) layer and the underlying granite regolith.
Lithic discontinuities were slightly indicated by the coarse fragment composition in $\mathrm{P}_{1}, \mathrm{P}_{3}$ and $\mathrm{P}$ 4, showing a different lithology and a bit higher content below the $2 \mathrm{Ck} 1$, Btg1 and $2 \mathrm{Btg} 2$ horizons, respectively (Table 3). As a consequence, the contribution of the allochthonous substrate may be considered as coming in two non-exclusive ways: i) as the addition of aeolian silt and formation of aeolian silt mantle (poor in coarse fragments), and/or ii) as the mixing of topsoil material with deposited allochthonous material that might have occurred during redistribution processes of particles along the slope before stabilization by vegetation (Martignier et al. 2012; Waroszewski et al. 2019).

\subsection{Geochemistry}

Considering the significant accretion of a silt fraction in the uppermost horizons, especially in profiles $\mathrm{P}_{3}, \mathrm{P}_{4}$ and $\mathrm{P} 6$ the question arises: Is the silt admixture really directly connected with aeolian admixture based on geochemical values? Similar investigations have been taken by many authors studying mountain areas, e.g. Kacprzak and Salamon (2013); Küfmann (2008); Loba et al. (2019); Martignier and Verrecchia (2013); Waroszewski et al. (2018a). Other authors (e.g. Galovic and Peh 2014; Scheib and Lee 2010; Waroszewski et al. 2018a) have noted aeolian silts are enriched by $\mathrm{Zr}$ and Hf; thus, these elements can be used to recognize aeolian silt admixture, even with weak intensity levels. The range of $\mathrm{Zr}$ and $\mathrm{Hf}$ concentrations characteristic of an aeolian silt contribution ranges from 237 to $453 \mathrm{mg} \cdot \mathrm{kg}^{-1}$ and 8 to $14 \mathrm{mg} \cdot \mathrm{kg}^{-1}$ for $\mathrm{Zr}$ and $\mathrm{Hf}$, respectively (Scheib et al. 2014). In this study, the content of $\mathrm{Zr}$ and $\mathrm{Hf}$ in soils $\mathrm{P}_{3}, \mathrm{P}_{4}$ and $\mathrm{P} 6$ (Table 5) exceeded the minimum values characteristic for the aeolian silt contribution into the soil. The input of allochthonous silt, since it was small, could be considered only within the Ap and $A B t$ horizons of $\mathrm{P} 4$ and $\mathrm{AB}$ and the $\mathrm{Btg} 1$ horizons of $\mathrm{P} 6$. In contrast, every horizon of $\mathrm{P}_{3}$ had a $\mathrm{Zr}$ and $\mathrm{Hf}$ content ranging from 8.3 to $9.1 \mathrm{mg} \cdot \mathrm{kg}^{-1}$ and 324.4 to 358.5 $\mathrm{mg} \cdot \mathrm{kg}^{-1}$, respectively (Tables 5 ), hence a weak but noticeable aeolian silt incorporation could be supposed within the whole solum. The weak admixture of silt was, however, responsible for the silty loam or silty clay loam texture. As noted by 
Waroszewski et al. (2019) such textures in the soil horizon need to be regarded as part of the mixed zones.

In contrast, in the soils P1, $\mathrm{P}_{2}$ and $\mathrm{P}_{5}$, geochemistry data (Table 5) did not show an allochthonous origin of soil material, i.e. not from aeolian silt (Küfmann 2008). In view of the above, it seems that the slight differences between the horizons were because of the transport of soil material on the slope, most likely of local origin (Chmal and Traczyk 1998; Kacprzak et al. 2010; Kacprzak and Derkowski 2007; Marcinkowski and MycielskaDowgiałło 2013; Waroszewski et al. 2016).

Considering the high heterogeneity of the major oxides (e.g. $\mathrm{Al}_{2} \mathrm{O}_{3}, \mathrm{Fe}_{2} \mathrm{O}_{3}, \mathrm{MgO}$, $\mathrm{Na}_{2} \mathrm{O}$, and $\mathrm{K}_{2} \mathrm{O}$ ), it could not be clearly stated whether they expressed the discontinuity indexes in the studied soils, especially in the case when no evident increasing or decreasing trend in the soil profile was noted (Table 5). The highest distinctness among the soils horizons was stated in case of soils $\mathrm{P}_{1}$ and $\mathrm{P}_{2}$, as visible on Harker diagrams (Figure 9). Such arrangements of major oxides seem to be the result of the transport and accumulation of soil material on the slope.

This explanation seems to be reasonable since the newly accumulated layer could be characterized by slightly different mineralogical compositions. The other soils $\mathrm{P}_{3}, \mathrm{P}_{4}, \mathrm{P}_{5}$ and $\mathrm{P} 6$ showed a more homogenous pattern in terms of major oxides (Figure 9), which could be the effect of a more advanced mixing process that led to homogenizing of the soil material (Waroszewski et al. 2018b).

The Harker diagram was also helpful to follow the significant changes in the content and
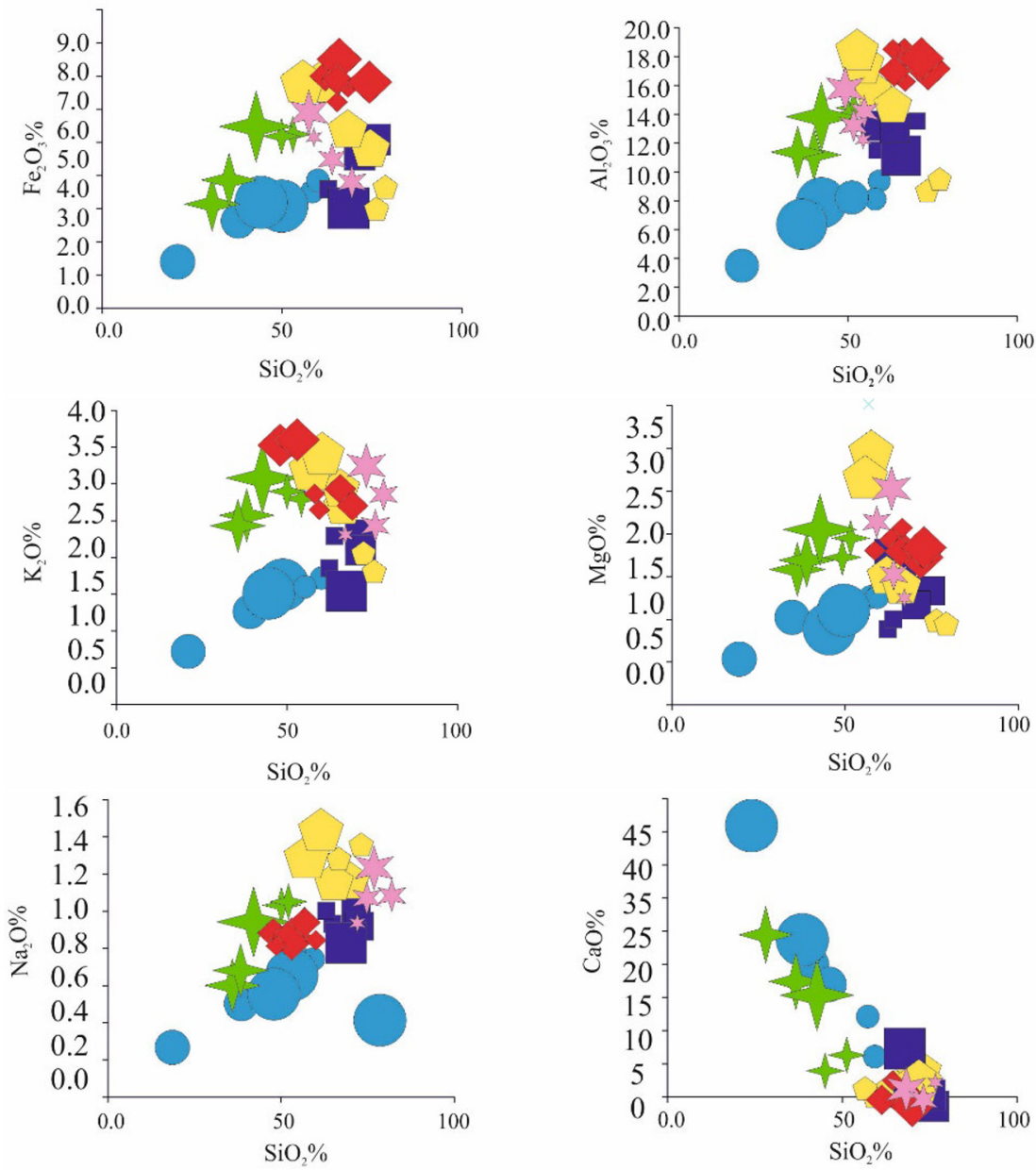

Explanations:

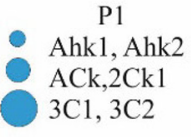

P4

$\mathrm{Ap}, \mathrm{ABt}$

2Btg1, 2Btg2

3BCtg1, 3BCtg2
P3

- $\mathrm{Ah}, \mathrm{Bt}$

Btg1, 2Btg2

2BCtg

$\mathrm{AB}$
$\mathrm{Btg} 1,2 \mathrm{Btg} 2$
$2 \mathrm{BCtg}$
Figure 9 Harker diagrams. The vertical ordinate represents weight percentage of some major oxides and the horizontal abscissa represent the weight percentage of $\mathrm{SiO}_{2}$.

distribution of $\mathrm{CaO}$ (Figure 9). Undoubtedly, the content of $\mathrm{CaO}$ in each horizon of $\mathrm{P}_{1}, \mathrm{P}_{2}$ and the 2BCtg horizon of $\mathrm{P}_{3}$ significantly distinguishes it from other samples (Figure 9). This is most likely associated with the occurrence of the very high content of calcium carbonate-rich coarse fragments (Kowalska et al. 2017). Further, horizon 2Ck1 of soil P1 was impoverished in most of the analysed oxides and trace elements but had the highest enrichment of $\mathrm{CaO}$ (Table 5). The obtained 
values may be related to the greater share of calcium carbonate in this horizon, almost 670 $\mathrm{g} \cdot \mathrm{kg}^{-1}$, which is almost two times higher than in horizons above (ACk) and below (3C1), as well as a high presence of pedogenic carbonates (Figure 6d). The differences in the $\mathrm{CaO}$ content within the soil profiles could result from the deposition of carbonate-free materials (aeolian silts) and their mixing with silt as well as the calcium carbonaterich parent material.

\subsection{Heavy mineral content and distribution}

Independent of the grain size distribution, coarse fragments and geochemistry, the lithic discontinuities in the studied soils could be welldistinguished by their heavy mineral distribution (Figure 4). The upper parts of studied soils were characterized by various contents of heavy minerals characterized by high resistance to weathering such as epidote, zircon, ilmenite, pyrite and garnets e.g.: almandine, pyrope, and andradite/glossular (Table 6; Figure 4). This distribution of heavy minerals clearly demonstrates evidence of the presence of a lithic discontinuity at the horizontal boundary between the uppermost and lowermost horizons (Waroszewski et al. 2013).

Attention is drawn to the fact that Orthoamphiboles (and Na- and Ca-amphiboles in case of P1, P2, P3), Ti-oxides and some types of garnets (e.g. pyrope) could be seen in the whole profile and/or within lower horizons, suggesting an igneous low- and high-grade metamorphic origin of soil material and long-lasting deposition of soil material from various sources. This suggests that translocation and deposition of soil material on the slope, already rich in those minerals and/or a high degree of soil mixing caused the quite striking level of homogeneity in the heavy mineral distribution (Martignier and Verrecchia 2013; Waroszewski et al. 2019).

Within soils where the signals of aeolian silt have been observed based on geochemical analyses, i.e. soils $\mathrm{P}_{3}, \mathrm{P}_{4}$ and $\mathrm{P}_{5}$, the content of heavy minerals also gave clear evidence of aeolian admixture. The differences in the heavy mineral content indicate a few possible sources of aeolian silts; the main primary environments are: (i) igneous and high to medium metamorphic and characterized by a high content of zircon in $\mathrm{P}_{3}$ (up to $15 \%$ in Ah and Btg1 horizon); (ii) low- and highgrade metamorphism in soil $\mathrm{P} 4$, as represented by the high content of almandine in upper soil horizons (up to $19.7 \%$ total in the Ap and $2 \mathrm{Btg} 1$ horizons); and (iii) hydrothermal and low-grade metamorphism as indicated in P6 through the presence of andradite/grossular (up to $16.2 \%$ in $\mathrm{AB}$ and Btg2 horizons) (Backheim and Hartemink 2013; Kacprzak and Derkowski 2007; Küfmann 2008; Palumbo et al. 2000; Waroszewski et al. 2019). This allochthonous material could also be seen in deeper horizons, as shown by the presence of pyrope in the $3^{\mathrm{BCtg} 2}$ horizon of $\mathrm{P}_{4}$ at $9.70 \%$ share and the high share of Ti-oxides within every soil horizon (Table 6; Figure 4). Similar results were described by Küfmann (2008) and Waroszewski et al. (2019).

Based on the assemblage of heavy minerals, it cannot be clearly stated whether the presence of such minerals has its source in local rock weathering or the additions of allochthonous materials from distant sources. However, considering that the Polish Carpathians consist mainly of sedimentary rocks, it cannot be suspected that the weathering of the parent materials was a source of silt so enriched in igneous and metamorphic minerals. In this case, it seems reasonable that the significant dominance of igneous and metamorphic assemblages of heavy minerals suggested rather the possible contribution of allochthonous aeolian silt, and its signature was noted even in the lower horizon (e.g. P4) depending on the depth of mixing process (Waroszewski et al. 2019; Waroszewski et al. 2020). The incorporated silts have a geochemical signature typical for loess or loess-derivates, which was confirmed by Waroszewski et al. (2019) in their studies over the aeolian silt admixture from the Sudeten Mts (SW Poland). It seems that the nearest source of such material is the loess cover at the foot of the Pieniny Mts.

\subsection{Micromorphology}

Although the changes in micromorphological features do not provide absolute evidence for the presence of a lithic discontinuity according to WRB (IUSS Working Group 2015), some significant differences in studied thin sections at the boundary of recognized lithic discontinuity were noted. For 
instance, a sudden change in b-fabric type was noted in soils $\mathrm{P} 2, \mathrm{P}_{4}$ and partially soil $\mathrm{P} 1$. In the case of these profiles, the surface horizons (horizons Ahk1 and Ahk2 of P1, Ah1 and Ah2 of P2 and $\mathrm{Ap}$ and $\mathrm{ABt}$ of $\mathrm{P} 4)$ represented an undifferentiated micromass (Table $7 \mathrm{~A}$ ). On the one hand, this can be a result of masking by other features e.g. a high occurrence of pedofeatures or organic matter. On the other, the low amount of interference colour may be also the result of slope processes that could modify the primary type of $b$ fabric (Mücher et al. 2010). Further, the sudden change of b-fabric at the boundary of the lithic discontinuity in soils $\mathrm{P}_{2}$ and $\mathrm{P}_{4}$ from undifferentiated into the coexistence of speckled, porostraited and granostriated undoubtedly could result from illuviation processes that favour the orientation of clay domains around voids or aggregates (Bullock et al. 1985). However, it could be also the effect of transport and deposition process of the soil material prior to reworking by mass movement on the slope (Mücher et al. 2010).

The secondary calcium carbonate occurred above and below the identified lithic discontinuity in soils $\mathrm{P}_{1}$ and $\mathrm{P}_{2}$, respectively (Figure $6 \mathrm{~b}, \mathrm{~h}$ ). Of course, the appearance of secondary carbonate in those soils was favoured by soil properties such as very stable conditions in these soils: i.e. high content of primary calcium carbonate, high $\mathrm{pH}$, high base saturation, moderate moisture, etc., which do not allow secondary carbonate dissolution (Zamanian et al. 2016). However, the secondary calcium carbonate distribution in $\mathrm{P}_{1}$ might be related to its texture: the relatively loose material might provide the conditions for easy movement of pedogenic calcium carbonate within the soil profile. In contrast, in soil P2 the change of texture (from silt clay loam to clay loam, Appendix 2) could favour the depletion of secondary carbonates in the upper part and their accumulation in lower horizons (Durand et al. 2010).

Finally, the soils $\mathrm{P}_{1}, \mathrm{P}_{2}$ and $\mathrm{P}_{5}$ showed changes within their coarse and fine units ratios in horizons below the lithic discontinuity, representing a more homogenous arrangement therein (Table $7 \mathrm{~A})$. This result would suggest that those horizons may have the same origin, which caused the similar arrangement of coarse and fine fragments, or the mixing process contributed to homogenizing of this part of the soil (Waroszewski et al. 2018).

\section{Conclusions}

In this study, the presence of a lithic discontinuity was identified in every studied soil using a multi-parameter approach (size-grain distribution, coarse fragments, heavy mineral content, geochemistry and a partial micromorphology analysis). The significant changes in grain size distribution (primarily in terms of silt and sand content) and high values of the Uniformity Values and the Lithological Discontinuity Index allowed the detection of a lithic discontinuity. Furthermore, the rapid increase of coarse fragments at the boundary of lithic discontinuities was noted. The coarse fragments within the soils showed different lithologies and various content.

The high heterogeneity within the soil profiles was confirmed through the distribution of the major oxides; however, their distribution did not indicate the lithic discontinuity clearly. Additionally, the most visible distinctions were noted in the case of $\mathrm{CaO}$ content, resulting from the deposition of carbonate-free materials (aeolian silts) and their mixing with the calcium carbonate-rich parent material.

Based on the high content of silt within the upper and middle horizons as well as the concentrations of $\mathrm{Hf}$ and $\mathrm{Zr}$, aeolian silt input into some of the studied soils should be taken into account. Furthermore, the analysis of the heavy minerals confirmed the incorporation of allochthonous material in upper (and in some cases also the middle) horizons of all profiles, which manifested itself by the presence of a high resistance-to-weathering minerals such as zircon, epidote and various types of garnets. In soils where the admixture of aeolian silt was noted through geochemical and granulometric analyses, the content of minerals such as e.g. zircon and garnet was also higher. However, the dominance of minerals typical for metamorphic and igneous rocks suggested the supply of aeolian silt was associated with loess deposits rather than local sedimentary bedrock.

The micromorphological features in some of 
the studied soils indicated a discontinuity within the profile, shown by changes in b-fabric pattern and the coarse and fine units ratio as well as the

\section{Acknowledgements}

This research was financed by the National Science Centre (Poland) (PRELUDIUM 14 project no. 2017/27/N/ST10/00342) and Ministry of Science and Higher Education of the Republic of Poland, No. BM-4112/17 and BM-2120/18. The authors are indebted to the reviewers for their constructive remarks and comments on an earlier version of the manuscript.

Electronic supplementary material: Supplementary materials (Appendixes 1-2) are available in the online version of this article at

\section{References}

Ahr SW, Nordt LC, Driese SG (2012) Assessing lithologic discontinuities and parent material uniformity within the Texas sandy mantle and implications for archaeological burial and preservation potential in upland settings. Quaternary Research (United States) 78(1): 60-71. http://doi.org/10.1016/j.yqres.2012.03.013

Ande OT, Senjobi B (2010) Lithologic discontinuity and pedogenetic characterization on an aberrant toposequence associated with a rock hill in South Western Nigeria. International Journal of the Physical Sciences 5(5): 596-604

Arnold RW (1968) Pedological significance of lithologic discontinuities. - Trans. 9th international Congress of Soil Science 4: 595-603.

Asikainen CA, Francus P, Brigham-Grette J (2007) Sedimentology, clay mineralogy and grain-size as indicators of $65 \mathrm{ka}$ of climate change from El'gygytgyn Crater Lake, Northeastern Siberia. Journal of Paleolimnology 37(1): 105122. http://10.1007/s10933-006-9026-5

Birkeland PW, Shroba RR, Burns SF, et al. (2003) Integrating soils and geomorphology in mountains - an example from the Front Range of Colorado. Geomorphology 55: 329-344. http://10.1016/So169-555X(03)00148-X

Bockheim JG, Douglass DC (2006) Origin and significance of calcium carbonate in soils of southwestern Patagonia. Geoderma 136: 751-762.

http://doi.org/10.1016/j.geoderma.2006.05.013.

Bockheim JG, Hartemink AE (2013) Distribution and classification of soils with clay-enriched horizons in the USA. Geoderma 209-210: 153-160.

http://doi.org/10.1016/j.geoderma.2013.06.009

Bockheim JG (2016) Genesis of soils with an abrupt textural contrast in the United States. Catena 137: 422-431. http://doi.org/10.1016/j.catena.2015.10.011

Bucci F, Mirabella F, Santangelo M, et al. (2016) Photo-geology of the Montefalco Quaternary Basin, Umbria, Central Italy. Journal of Maps 5647:1-9.

http://doi.org/10.1080/17445647.2016.1210042

Bullock P, Fedoroff N, Jongerius A, et al. (1985) Handbook for Soil Thin Section Description. Waine Research Publications Wolverhampton, UK. pp 152. occurrence and distribution of secondary calcium carbonate.

https://doi.org/10.1007/s11629-019-5842-8.

Open Access This article is distributed under the terms of the Creative Commons Attribution 4.0 International License (http://creativecommons. org/licenses/by/4.0/), which permits unrestricted use, distribution, and reproduction in any medium, provided you give appropriate credit to the original author(s) and the source, provide a link to the Creative Commons license, and indicate if changes were made.
Butler BE (1959) Periodic Phenomena in Landscapes as a Basis for Soil Studies. CSIRO, Melbourne, Australia, Soil publication 14 .

Caspari T, Baeumler R, Norbu C, et al. (2006) Geochemical investigation of soils developed in different lithologies in Bhutan, Eastern Himalayas. Geoderma 136(1-2): 436-458. http://doi.org/10.1016/j.geoderma.2006.04.017

Chapman SL, Horn ME (1968) Parent material uniformity and origin of silty soils in northwest Arkansas based on zirconium-titanium contents. Soil Science Society of America Journal 32: 265-271.

https://doi.org/10.2136/sssaj1968.03615995003200020030x

Chmal H, Traczyk A (1998) Postglacial morphological development of the Karkonosze and Izerskie Mountains in the light of river, limnic and slope sediments analysis. In: Sarosiek J. (Ed.), Geoecological problems of the Karkonosze Mountains. Poznan. pp 81-87. (In Polish, with English abstract)

Costantini EAC, Damiani D (2004) Clay minerals and the development of Quaternary soils in central Italy. Revista Mexicana de Ciencias Geologicas 21(1): 144-159.

Cremeens DL, Mokma DL (1986) Argillic horizon expression and classification in the soils of two Michigan hydrosequences. Soil Science Society of America Journal 50: 1002-1007. https://doi.org/10.2136/sssaj1986.03615995005000040034X

Durand N, Monger HC, Canti MG (2010) Calcium carbonate features. In: Stoops G, Marcelino V, Mees F (eds.), Interpretation of Micromorphological Features of Soils and Regoliths. Elsevier, Amsterdam 149-194. https://doi.org/10.1016/C2009-0-18081-9

FAO (2006) Guidelines for Soil Description. fourth ed. pp109. Rome: FAO.

Fedoroff N, Courty MA, Guo Z (2010) Palaeosoils and Relict Soils. In: Marcelino V, Mees F. (Eds.), Interpretation of Micromorphological Features of Soils and Regoliths. Elsevier, Amsterdam, 623-662. https://doi.org/10.1016/C2009-0-18081-9

Fedo CM, Nesbitt HW, Young GM (1995) Unraveling the effects of potassium metasomatism in sedimentary rocks and paleosols with implications for paleoweathering conditions 
and provenance. Geology 23: 921-924. https://doi.org/10. 1130/0091-7613(1995)023<0921:UTEOPM>2.3.CO;2

Fernández-Lavado C, Furdada G, Marqués MA (2007) Geomorphological method in the elaboration of hazard maps for flash-floods in the municipality of Jucuarán (El Salvador). Natural Hazards and Earth System Science 7: 455-465.

Galović L, Peh Z (2014) Eolian contribution to geochemical and mineralogical characteristics of some soil types in Medvednica Mountain, Croatia. Catena 117: 145-156. https://doi.org/10.1016/j.catena.2013.12.016

GeoLog (2019) https://geolog.pgi.gov.pl/ (Accessed on October 2019).

Gunal H, Ransom MD (2006) Genesis and micromorphology of loess-derived soils from central Kansas. Catena 65(3): 222236.https://doi.org/10.1016/j.catena.2013.12.01610.1016/j.ca tena.2005.11.018

Hall R, Davis LG, Willis S, et al. (2005) Radiocarbon, soil, and artifact chronologies for an early southern Oregon coastal site. Radiocarbon 47(3): 383-394.

Holliday VT, Surovell T, Meltzer DJ, et al. (2014) The Younger Dryas impact hypothesis: A cosmic catastrophe. Journal of Quaternary Science 29(6): 515-530. https://doi.org/10.1016/So016-7061(02)00377-4

Howard JL, Olszewska D (2011) Pedogenesis, geochemical forms of heavy metals, and artifact weathering in an urban soil chronosequence, Detroit, Michigan. Environmental Pollution 159: 754-761.

https://doi.org/10.1016/j.envpol.2010.11.028

Ibrahim MA, Lee Burras C, Steele J, et al. (2011) Munterville: A New Soil Series in Iowa. Soil Survey Horizons 52(4): 103-110. https://doi.org/10.2136/ssh2011-52-4-1

IUSS Working Group WRB (2015) World Reference Base for Soil Resources 2014, update 2015. International soil classification system for naming soils and creating legends for soil maps. World Soil Resources Reports No. 106. FAO, Rome, 182.

Jaworska H, Dabkowska-Naskręt H, Kobierski M (2014) The influence of litho- and pedogenic processes on Luvisols formation of selected area of Vistula Glaciation. Geological Quarterly 58(4): 685-694. https://doi.org/10.7306/gq.1175

Kacprzak A, Derkowski A (2007) Cambisols developed from cover-beds in the Pieniny Mts. (southern Poland) and their mineral composition. Catena 71 (2): 292-297.

https://doi.org/10.1016/j.catena.2007.01.004

Kacprzak A, Klimek M, Wójcik-Tabol P, et al. (2010) Lithological discontinuities in the soil catena of Góra Zamkowa at Lanckorona (Wieliczka Foothills, Southern Poland), Prace Geograficzne 123: 83-98.

Kacprzak A, Salamon P (2013) Properties and classification of soils developed from Aeolian and flysch materials in the Wieliczka Foothills (Southern Poland). Gruntoznavstvo 14: 52-62.

Kondracki J (1989) Carpathians. Wydawnictwa Szkolne i Pedagogiczne, Warszawa. (In Polish)

Kowalska J, Mazurek R, Gąsiorek M, et al. (2016) Soil pollution indices conditioned by medieval metallurgical activity - a case study from Krakow (Poland). Environmental Pollution 218: 1023-1036. https://doi.org/10.1016/j.envpol.2016.08.053

Kowalska J, Kajdas B, Zaleski T (2017) Variability of morphological, physical and chemical properties of soils derived from carbonate-rich parent material in the Pieniny Mountains (south Poland). Soil Science Annual 68 (1): 27-38. https://doi.org/10.1515/ssa-2017-0004

Kowalska JB, Zaleski T, Józefowska A, et al. (2019) Soil formation on calcium carbonate-rich parent material in the outer Carpathian Mountains - A case study. Catena 174: 436451. https://doi.org/10.1016/j.catena.2018.11.025

Krasilnikov PV García Calderóna N, Sedov SN, et al. (2005) The relationship between pedogenic and geomorphic processes inmountainous tropical forested area in Sierra Madre del Sur, Mexico. Catena 62: 14-44.

https://doi.org/10.1016/j.catena.2005.02.003
Kuzila MS (1995) Identification of multiple loess units within modern soils of Clay County, Nebraska. Geoderma 65: 45-57. https://doi.org/10.1016/0016-7061(94)00030-E

Küfmann C (2008) Are cambisols in alpine karst autochthonous or Eolian in origin. Arctic, Antarctic, and Alpine Research 40: 506-518. https://doi.org/10.1657/1523-0430(o6-091)[KUEF MANN]2.0.CO;2

Liebens J (1999) Characteristics of soils on debris aprons in the Southern Blue Ridge, North Carolina. Physical Geography 20: 27-52. https://doi.org/10.1080/02723646.1999.10642667

Ligęza S (2009) Determination of lithological discontinuities within the soils. Soil Science Annual 6o(1): 77-84.

Lityński T, Jurkowska H, Gorlach E (1976) ChemicalAgricultural Analysis. PWN, Warszawa 332 (In Polish).

Loba A, Sykuła M, Kierczak J, et al. (2019) In situ weathering of rocks or aeolian silt deposition: key parameters for verifying parent material and pedogenesis in the Opawskie Mountains - a case study from SW Poland. Journal of Soils and Sediments 20(1):435-451. https://doi.org/10.1007/s11368-019-02377-5

Lorz C, Phillips J (2006) Pedo-Ecological Consequences of Lithological discontinuities in soils. Examples from Central Europe. Journal of Plant Nutrition and Soil Science 169: 573581. https://doi.org/10.1002/jpln.200521872

Lorz C (2008) Lithological Discontinuous Soils - Archives for the Pedo-Geochemical Genesis of the Soil-Regolith-Complex? Zeitschrift für Geomorphologie, Supplementary Issues 52: 119-132. https://doi.org/10.1127/0372-8854/2008/0052S2-0119

Lorz C, Frühauf M, Mailänder R, Phillips JD (2010) Lithologic discontinuities in cover beds influencing soil evolution and soil properties. Geophysical Research Abstracts 12: 63-68.

Lorz C et al. (2013) Influence of Cover Beds on Soils. In: Kleber A, Terharst B (Eds.), Mid-Latitude Slope Deposits (Cover Beds), Elsevier. pp 95-125.

Marcinkowski B, Mycielska-Dowgiałło E (2013) Heavy-mineral analysis in Polish investigations of Quaternary deposits: a review. Geologos 19: 1-2, 5-23.

https://doi.org/10.2478/logos-2013-0002

Martignier L, Adatte T, Verrecchia EP (2012) Bedrock versus superficial deposits in the Swiss Jura Mountains: what is the legitimate soil parent material? Earth Surface Processes and Landforms 38: 331-345.

https://doi.org/10.1016/j.aeolia.2015.05.003

Martignier L, Verrecchia EP (2013) Weathering processes in superficial deposits (regolith) and their influence on pedogenesis: A case study in the Swiss Jura Mountains. Geomorphology 189: 26-40. https://doi.org/10.1016/j.geomorph.2012.12.038

Martignier L, Nussbaumer M, Adatte T, et al. (2015) Assessment of a locally-sourced loess system in Europe: the Swiss Jura Mountains. Aeolian Research 18: 11-21. https://doi.org/10.1016/j.aeolia.2015.05.003

Migoń P, Kacprzak A (2014) Lateral diversity of regolith and soils under a mountain slope - implications for interpretation of hillslope materials and processes, Central Sudetes, SW Poland. Geomorphology 221: 69-82. https://doi.org/j.geomorph.2014.06.003

Mücher H, van Steijn H, Kwaad F (2010) Colluvial and mass wasting deposits. In: Stoops G, Marcelino V, Mees F. (eds.), Interpretation of Micromorphological Features of Soils and Regoliths. Elsevier, Amsterdam 37-48.

https://doi.org/10.1016/j.catena.2013.12.016https://doi.org/ 10.1016/C2009-0-18081-9

Muhs DR (2018) The geochemistry of loess: Asian and North American deposits compared. Journal of Asian Earth Sciences155: 81-115.

https://doi.org/10.1016/j.jseaes.2017.10.032

Munsell (1975) Standard Soil Color Charts.

Musztyfaga E, Kabała C (2015) Lithological discontinuity in Glossic Planosols (Albeluvisols) of Lower Silesia (SW Poland). Soil Science Annual 66(4): 180-190. https://doi.org/10.1515/ssa-2015-0035 
Otrębska-Starklowa B, Hess M, Olecki Z, et al. (1995) Karpaty Polskie. In: Warszyńska J (Eds.) Klimat. Uniwersytet Jagielloński 31-48. (In Polish)

Oszczypko N (1995) Karpaty Polskie. In: Warszyńska J (Eds.), Budowa geologicnza. Uniwersytet Jagielloński 15-22 (in Polish).

Palumbo B, Angelone M, Bellanca A, et al. (2000) Influence of inheritance and pedogenesis on heavy metal distribution in soils of Sicily, Italy. Geoderma 95: 3-4, 247-266.

https://doi.org/10.1016/So016-7061(99)0oo90-7

Phillips JD (2004) Geogenesis, Pedogenesis, and Multiple Causality in the Formation of Texture-Contrast Soils. - Catena 58(2): 275-295.

https://doi.org/10.1016/j.catena.2004.04.002

Philips JD (2007) Development of texture contrast soils by a combination of bioturbation and translocation, Catena 70 : 92-104. https://doi.org/10.1016/j.catena.2006.08.002

Pike AS, Scatena FN, Wohl EE (2010) Lithological and fluvial controls on the geomorphology of tropical montane stream channels in Puerto Rico. Earth Surface Processes and Landforms 35(12): 1402-1417.

https://doi.org/10.1002/esp.1978

Polish Standard (1998) Soil and mineral soil materials sampling and determination of particle size distribution. PNR-04032. Polish Committee for Standardization, Warszawa (In Polish).

Priori S, Costantini EAC (2010) Geographic relevance of Late Pleistocene and Middle Holocene aeolian deposits in Central Tuscany (Italy). 19th World Congress of Soil Science, Soil Solutions for a Changing World Brisbane, Australia 9-12.

Sauer D, Schülli-Maurer I, Wagner S, et al. (2015) Soil development over millennial timescales-a comparison of soil chronosequences of different climates and lithologies. IOP Conference Series: Earth and Environmental Science 25(1): 12009. https://doi.org/10.1088/1755-1315/25/1/012009

Schaetzl RJ (1998) Lithologic Discontinuities in some soils on Drumlins: theory, detection, and application. Soil Science 163(7): 570-590.

Schaetzl R, Anderson S (2005) Soils, Genesis and Geomorphology. Cambridge (Cambridge University Press), 817.

Schaetzl RJ (2008) The distribution of silty soils in the Grayling Fingers region of Michigan: evidence for loess deposition onto frozen ground. Geomorphology 102: 287-296.

Scheib AJ, Birke M, Dinelli E, et al. (2014) Geochemical evidence of aeolian deposits in European soils. Boreas 43: 175-192. https://doi.org/10.1111/bor.12029

Scheib AJ, Lee J (2010) Mapping Late Pleistocene and Holocene aeolian sediments in East Anglia, UK: the application of regionalscale geochemical data. Quaternary Newsletter 120: 5-14.

Sha LK, Chappelle BW (1999) Apatite chemical composition, determined by electron microprobe laser ablation inductively coupled plasma mass spectrometry, as a probe into granite petrogenesis. Geochimica et Cosmochimica Acta 63: 38613881. https://doi.org/10.1016/Soo16-7037(99)o0210-o

Semmel A, Terhorst B (2010) The concept of periglacial cover beds in central Europe: A review. Quaternary International 222: 120-128. https://doi.org/10.1016/j.quaint.2010.03.010

Skiba S (1995) Karpaty Polskie. In: Warszyńska J (Eds.), Pokrywa glebowa. Uniwersytet Jagielloński 69-76 (In Polish).

Stoops G (2003) Guidelines for analysis and description of soil and regolith thin sections. Soil Science Society of America, Inc.
Madison, Wisconsin, USA, 184. https://doi.org/10.1017/So02185960322339X

Stoops G, Marcelino V, Mees F (2010) Micromorphological Features and Their Relation to Processes and Classification: General Guidelines and Keys. In: Stoops G, Marcelino V, Mees F (Eds.) Interpretation of Micromorphological Features of Soils and Regoliths. Elsevier, Amsterdam 15-36. https://doi.org/10.1016/C2009-0-18081-9

Towpasz K, Zemanek B (1995) Karpaty Polskie. In: Warszyńska J (Eds.), Szata Roślinna. Uniwersytet Jagielloński 77-94. (In Polish).

Waroszewski J, Kabała C, Koszelnik K (2013) Litological discontinuities in Podzols developed from Upper Cretaceous sandstones in the Stołowe Mountains, Geographic Works. pp 87-100.

Waroszewski J, Malkiewicz M, Mazurek R, et al. (2015) Lithological discontinuities in Podzols developed from sandstone cover beds in the Stolowe Mountains (Poland). Catena 126: 11-19. https://doi.org/10.1016/j.catena.2014.10.034

Waroszewski J, Egli M, Kabała C, et al. (2016) Mass fluxes and clay mineral formation in soils developed on slope deposits of the Kowarski Grzbiet (Karkonosze Mountains, Czech Republic/Poland). Geoderma 264: 363-378.

http://doi.org/10.1016/j.geoderma.2015.08.044

Waroszewski J, Sprafke T, Kabała C, et al. (2018a) Aeolian silt contribution to soils on mountain slopes (Mt. Ślęża, southwest Poland). Quaternary Research 89(3):1-16. https://doi.org/10.1017/qua.2017.76

Waroszewski J, Egli M, Brandová D, et al. (2018b) Identifying slope processes over time and their imprint in soils of medium-high mountains of Central Europe (the Karkonosze Mountains, Poland). Earth Surface Processes and Landforms 43: 1195-1212. https://doi.org/10.1002/esp.4305

Waroszewski J, Sprafke T, Kabała C, et al. (2019) Tracking textural, mineralogical and geochemical signatures in soils developed from basalt-derived materials covered with loess sediments (SW Poland). Geoderma 337: 983-997. https://doi.org/10.1016/j.geoderma.2018.11.008

Waroszewski J, Sprafke T, Kabała C, et al. (2020) Chronostratigraphy of silt-dominated Pleistocene periglacial slope deposits on Mt. Ślęża (SW, Poland): Palaeoenvironmental and pedogenic significance. Catena 190: 104549. https://doi.org/10.1016/j.catena.2020.104549

Warszyńska J (1995) Karapty Polskie. Przyroda, człowiek i jego działalność. Uniwersytet Jagielloński, Kraków (in Polish).

Weindorf DC, Chakraborty S, Abdalsatar A et al. T (2015) Lithologic discontinuity assessment in soils via portable X-ray fluorescence spectrometry and visible near-infrared diffuse reflectance spectroscopy. Soil Science Society of America Journal 79(6): 1704-1716. https://doi.org/10.2136/sssaj2015.04.0160

Wicik B (1986) Asynchronicity of the weathering and sedimentation processes in the lakes of the Tatra and Karkonosze Mountains in the Post-Glacial period. Przeglad Geograficzny 58: 809-823 (in Polish, with English abstract).

Yang F et al. (2016) Pedogenetic interpretations of particle-size distribution curves for an alpine environment. Geoderma 282: 9-15. https://doi.org/10.1016/j.geoderma.2016.07.003

Zamanian K, Pustovoytov K, Kuzyakov Y (2016) Pedogenic carbonates: Forms and formation processes. Earth-Science Reviews 157: 1-17. https://doi.org/10.1016/j.earscirev.2016.03.003 